\title{
Depositional environment of the glacigenic deposits from the Holy Cross Mountains (Poland) - interpretation based on macro- and microstructure analyses
}

\author{
Małgorzata LUDWIKOWSKA-KĘDZIA ${ }^{1, *}$ and Halina PAWELEC ${ }^{2}$ \\ 1 Jan Kochanowski University, Institute of Geography, Świętokrzyska 15, 25-435 Kielce, Poland \\ 2 University of Silesia, Faculty of Earth Sciences, Będzińska 60, 41-200 Sosnowiec, Poland
}

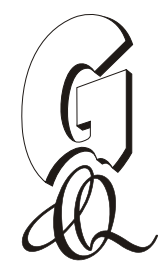

\begin{abstract}
Ludwikowska-Kędzia, M., Pawelec, H., 2014. Depositional environment of the glacigenic deposits from the Holy Cross Mountains (Poland) - interpretation based on macro- and microstructure analyses. Geological Quarterly, 58 (4): 807-826, doi: $10.7306 / g q .1200$

In this paper an attempt is made to identify the depositional environment of glacigenic deposits from the central part of the Holy Cross Mountains (Kielce-Łagów Valley). In this area, the primary glacial relief is very poorly visible, mainly due to its modification by subsequent denudation processes. The study is based on detailed sedimentological (macro- and microstructural) analysis of the deposits. The bottom part of the deposits consists of gravelly and sandy facies. They are overlain by diamicton facies, with a small proportion of sandy facies. Clayey/silty facies occur in minor quantities. The investigations indicate that these deposits represent an ice-marginal environment. Local stagnation of the ice sheet lobe was controlled by the geological structure of bedrock (karstified and faulted limestones) and the features of a fossil valley. The ice-marginal depositional environment is indicated by the predominance of sediment-gravity flow deposits, a low proportion of sorted deposits, as well as the interfingering/alternating of mass flow deposits and waterlain deposits. Deformation occurring in the deposits is of gravitational origin. They also show traces of periglacial processes. The deposits constituted an ice-marginal moraine (dry end moraine with limited topographic expression). Micromorphological analyses provided data for genetic identification of the deposits, and allowed the inference about rheology of deposition and deformation processes. However, in some cases, they did not allow unequivocal genetic classification of the deposits. The results of presented investigations confirm the opinion that detailed and complete explanation of deposit origin requires both micromorphological analyses and macroscopic field sedimentological and structural studies.
\end{abstract}

Key words: glacigenic deposits, ice-marginal environment, macro- and microstructures, Pleistocene, Holy Cross Mountains, Poland.

\section{INTRODUCTION}

In the Holy Cross Mountains, particularly in its central part, the Pleistocene glacigenic deposits are poorly understood, both in respect of modes of deposition and stratigraphy. Until now, it has been assumed that the deposits are related to the South Polish Glaciations (San 1 and San 2 = Cromerian and Elsterian) and/or to the Middle Polish Glaciations (Saalian; Czarnocki, 1950; Walczowski, 1962 1964; Filonowicz, 1969, 1978, 1980; Łyczewska, 1971; Różycki, 1972a, b; Kowalski et al., 1979; Lindner, 1984, 2004; Kowalski, 1988, 1995, 2002). It is difficult to determine accurately the relationship between the Quaternary deposits and the geomorphology, because the periglacial denudation and weathering processes have resulted in considerable modification of the Pleistocene glacial landscape.

The main aim of this paper is to identify the depositional environment of the Pleistocene deposits from the central part of

\footnotetext{
* Corresponding author, e-mail: margludwik@gmail.com

Received: August 26, 2013; accepted: June 27, 2014; first published online: November 3, 2014
}

the Holy Cross Mountains, based on detailed sedimentological, lithofacies, macro- and microstructural analyses. Previous petrographic and mineralogical analyses of these deposits indi-

Fated theiा glacigenाic origin (Ludwikowska-Kęuzia aाru Pawelec, 2011). Scandinavian erratics have been found in hese deposits. Moreover, the composition of heavy mineral assemblage is typical of tills in Poland (cf. Racinowski, 2008, 2010), i.e. with the following order of main minerals: G-Am-Z (K-St; garnets-amphiboles-zircon; accompanied by kyanite and staurolite; Ludwikowska-Kędzia, 2013).

The paper refers to the current scientific discussion on the possibility of identification of glacigenic deposits based on microstructural analysis. Investigations of tills have an imporant position in microstructural sedimentological studies. They have resulted in the identification of structures typical of glacigenic diamictons (e.g., Van der Meer, 1993; Hiemstra and Van der Meer, 1997; Menzies, 2000; Hiemstra and Rijsdik, 2003; Kilfeather et al., 2008). The investigations concern mostly the relationship between matrix and skeleton grains, and allow the inference about rheology of deposits - based on the description of deformations (ductile, brittle and complex) as well as microstructures formed by pore-water. The results of subsequent investigations indicate that not individual microstructures are diagnostic but rather their coincidence in separate till types 


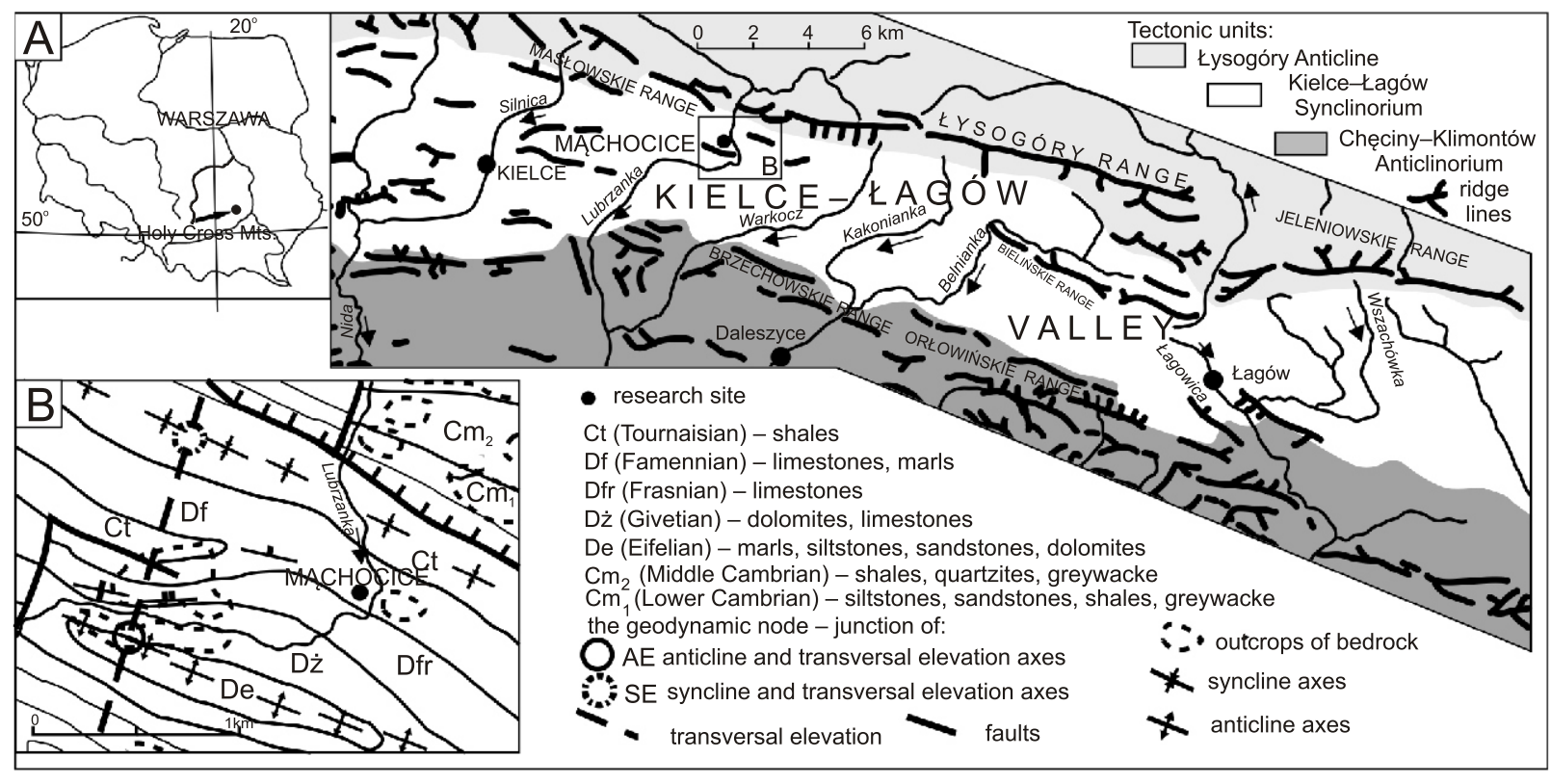

Fig. 1. Location of the study area in relation to: A - teftdnic units (after Czarnocki, 1957) and orographic units (after Wróblewski, 1977) of Holy Cross Mountains, B -t tectonic sketch (after Filonowicz, 1980; Kowalski, 1995)

(Hiemstra and Rijsdijk, 2003; Menzies and Zaniewski, 2003; Phillips, 2006; Van der Meer et al., 2011). Modern research on the subglacial till micromorphology mostly aims to determine ice dynamics (e.g., Hiemstra and Van der Meer, 1997; Menzies, 2000; Evans and Hiemstra, 2005).

The significance of individual microstructures is still discussed but it is commonly accepted that the sedimentology of deposits may be fully determined if macroscopic observations are supplemented with microscopic studies (e.g., Bertran and Texier, 1999; Ruszczyńska-Szenajch et al., 2003; Phillips, 2006; Van der Meer et al., 2011).

\section{STUDY AREA}

The investigations were conducted in field sections situated in the central part of the Holy Cross Mountains, near the village of Mąchocice Kapitulne (15 km NW of Kielce Fig. 1A), in the Kielce-Lagów Synclinorium of the Paleozoid core (Fig. 1A). The synclinorium is expressed in the topophy by the vastdepression of the Kielce-Łagów Valley (Wróblewski, 1977).

The Quaternary sediments are underlain by Upper Devo hian dolomites and limestones as well as Lower Carboniferous shales forming together the Miedziana Góra Syncline Filonowicz, 1969; Konon, 2008; Fig. 1B). Water permeability of the Upper Devonian rocks is medium (to low) but locally lime\$tones have high permeability (Prażak, 2012). The Carbonifer pus rocks are characterized by low permeability. Relief of the Quaternary basement in the bottom of the Kielce-Łagów Valley is variable. In the area investigated in detail, the Upper Devo hian rocks form a local_high related in part to the line o ransversal elevation (Kowalczewski, 1963), and probably to he neofectonic up lift of the Paleozoic bedrock (Kowalski, 1995$)$ Fig. 1B).To the south, this high borders on a depression of the Paleozoic bedrock, which is probably of karst origin. It was formed within the Middle and Upper Devonian limestones and dolomites, which were cut by numerous faults. Lithological susceptibility of the bedrock to the development of karst phenomena is enhanced here by rock fractures. The varying degree of fracturing is due to the tectonic activity in the study area (Prażak, 2012).

The Quaternary in the Kielce-Łagów Valley is represented by surface deposits highly variable in lithology (clays, sands, gravels, tills), origin and age (e.g., Filonowicz, 1969, 1980; Łyczewska, 1971; Ludwikowska-Kędzia, 2000; Kowalski, 2002; Sołtysik, 2002; Ludwikowska-Kędzia et al., 2006).

The sife under study is sifuated at $280-200 \mathrm{~m}$ a.s.l., on the NE slope of a erosional-denudation spur (Fig. 2). This is also the western side of the modern valley of the Lub zanka River. ts fossil valley in the study zone has asymmetrip sides cut in Devonian limestone. The western side is low, long, gently inclined and covered with loose deposits, while the eastern side is higher and steep (rock wall; Fig. 2B).

The investigated site is a $50 \mathrm{~m}$ long sandp t wall cutting ransversely (from $\mathrm{N}$ to $\mathrm{S}$ ) the erosional-denudation spur and the adjacent part of the Vistulian terrace of the Lulrzanka River valley (Fig. 2B). About $3 \mathrm{~m}$ thick glacigenic deposits are exposed over a distance of about $30 \mathrm{~m}$ in the highest part of the sandpit. The walls of glacigenic deposits, with the W-E orientation and northern aspect, were studied in detail.

\section{METHODS}

Field work included: (1) a geological and geomorphological survey, (2) a detailed sedimentological analysis of profiles, and (3) sediment sampling for grain-size and microscopic analyses. ithofacies were labelled according to the codes of Miall (1978, 1985), and Krüger and Kjær (1999), considengadificafion (Zieliński and Pisarska-Jamroży, 2012: Table 1). The gehetic code according to Miall (1985) with some modification was also applied (Table 2). In addition to the investigations in the exposure, two boreholes were drilled (nos. 1, 2: Fig. 2B on the cross-section), and archived boreholes were also used (no. 3; Fig. 2B)

Silty/sandy deposits and diamictons were sampled for microstructural analyses. Six undisturbed samples were taken in a vertical section from the surface with the $\mathrm{W}-\mathrm{E}$ orientation, 

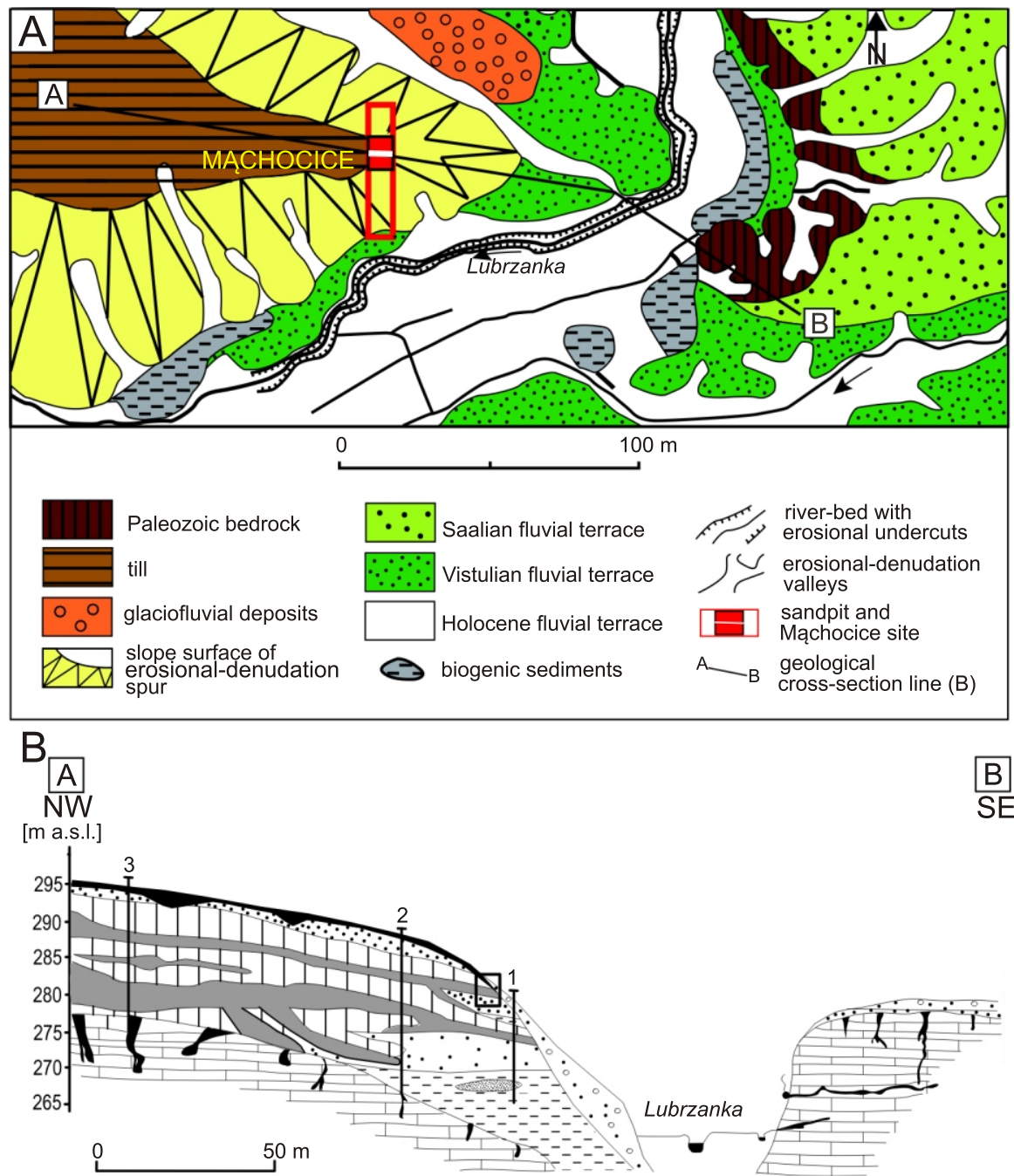

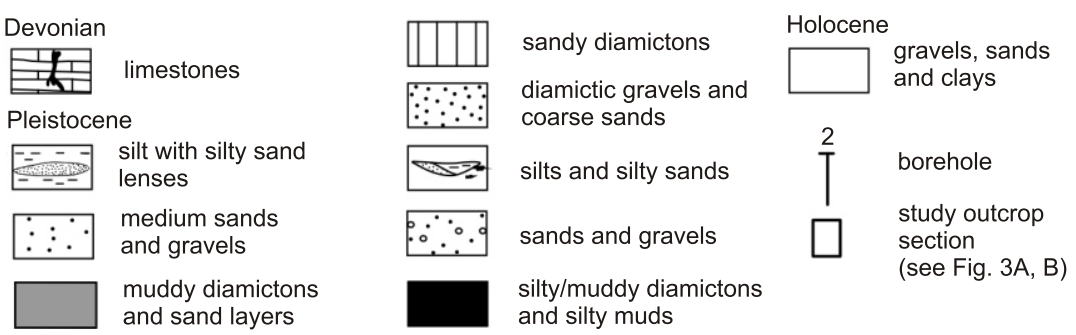

Fig. 2A-location of glacial deposits in the Machocice site in the geomorphological sketch of the study area (after Ludwikowska-Kędzia and Pawelec, 2011; Ludwikowska-Kędzia, 2013), origin and age of deposits (after Filonowicz, 1968); B - geological cross-section through the Lubrzanka River valtey and the study site

inclined along the side of the Lubrzanka River valley (Fig. 3A). The samples were impregnated with polyester resin according to the method described by Brewer (1964) and Stoops (2003). The then-prepared thin section 76 m in size. They were analysed under an optical microscope at up to $20 \times$ magnification.

\section{ANALYSIS OF THE DEPOSITS}

The exposed glacigenic deposits overlie a series of lacustrine deposits filling the fossil valley of the Lubrzanka River (Fig. 2B).
The following nine main depositional units have been distinguished in the exposu e(FIg. 3): gravels, sandy grapels and sands (unit I), diamictons with clayey matrix (unit II), silty sand layers (unit III), silty/sandy complex (unit IV), detached lump of pliamictic gravels (unit V), diamictons with sandy matrix (unit VI), gravelly pavement and sandy/claye breccia (unit VIla,b), fissure structure-filling sands (unit VIII), and silty/clayey diamictons (unit IX).

UNIT I

The lithofacies ale represented by gravels, sandy gravels, and medium- and coarse-grained sands (Fig. 3). Gravels (Gm) 

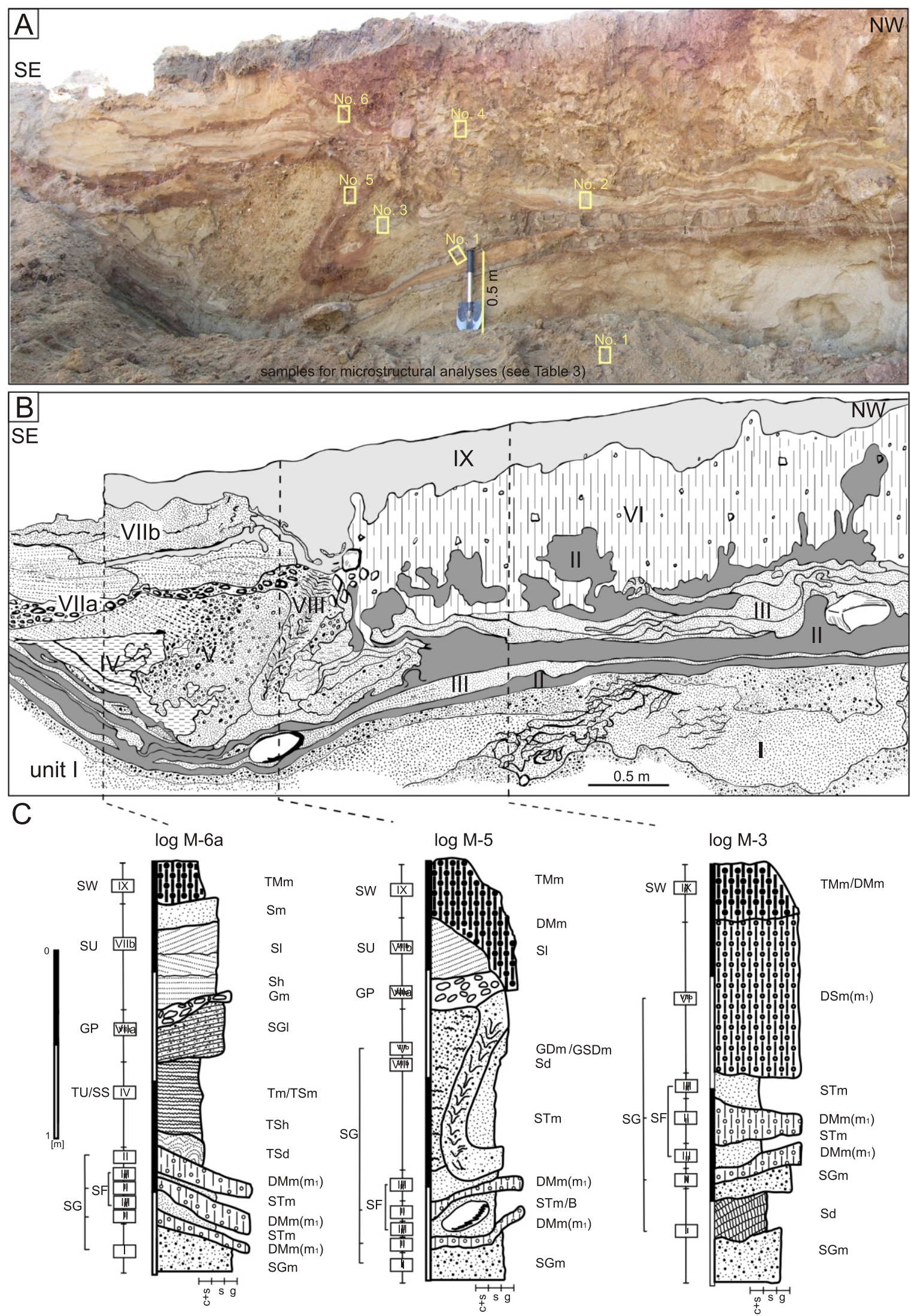

Fig. 3. Glacigenic deposits in the Mąchocice site: A - photograph of the exposure, B - lithological sketch, C - sedimentological logs (after Ludwikowska-Kędzia, 2013, nodified)

Sm - lithofacies code; SU - lithogenetic code se Tables 1 and 2 I - unit; c+s - clay and silt, s - sand, g-gravel 
Lithofacies code symbols used in this study

\begin{tabular}{|c|c|}
\hline Code & Texture \\
\hline B & boulder \\
\hline G & gravel \\
\hline GS & sandy gravel \\
\hline GD & diamictic gravel \\
\hline S & sand \\
\hline SG & gravelly sand \\
\hline ST & silty sand \\
\hline GSD & diamictic sandy gravels \\
\hline $\mathrm{T}$ & silt \\
\hline TS & sandy silt \\
\hline M & mud (clay) \\
\hline TM & muddy (clayey) silt \\
\hline DS & sandy diamicton \\
\hline DM & muddy (clayey) diamicton \\
\hline \multicolumn{2}{|r|}{ Structure } \\
\hline $\mathrm{m}$ & massive \\
\hline$\left(m_{1}\right)$ & matrix-supported; clast poor $(<15 \%)$ \\
\hline $\mathrm{h}$ & horizontal stratification/lamination \\
\hline I & low-angle $\left(<15^{\circ}\right)$ cross-stratification \\
\hline d & deformed \\
\hline
\end{tabular}

and sandy gravels (GSm) are characterized by massive structure. These deposits laterally grade into and are separated by massive sands (Sm), locally with horizontal lamination (Sh) or low-angle cross-stratification (SI). There are also zones of homogeneous sand (without clay particles), distinguished by a lighter colour. Boundaries between the beds are uneven. Water-escape structures, resembling dish and pillar structures, are visible in the deposits.

Their colour (in dry deposit) is distinctively white due to a high proportion of the Miocene detrital and coralline algal limestones as well as the Mesozoic siliceous chalk and limestones. Most of gravel grains (also the fragments of Scandinavian rocks) have smooth surfaces and rounded edges.

The unit I succession is locally characterized by inverse grading. In places, the top part of unit I is brown and enriched in the silty/clayey fraction cemented by iron compounds. Cell-shaped structures, filled with gravelly sand, occur in this part.

Interpretation. Lithofacies $\mathrm{Gm}, \mathrm{GSm}$ and $\mathrm{Sm}$ (Sh, SI) were formed in the environment of generally high and variable flow energy. The occurrence of water-escape structures may indicate fast sediment deposition (Gradziński et al., 1986).

The $\mathrm{fm}$ (GSm), Sh and SI lithofacies may have formed at the trans tion from subcritical to supercritical flow (uppe-stage plane-bed; Zieliński, 1998). They may represent shallow, ephemeral currents of sheet-flood type (Miall, 1977) and/or meltstreams. These deposits might have been spread subaque uusly as flows. Therefore the Gm (GSm), Sm association facie s may have been resulted from secondary processes subaqueous cohesionless debris flows. These flows can also originate by the failure of cohesionless materials on supaqueous slop@s (Benn and Evans, 2010). The following deposit features indicate this type of flows: inverse grading (locally), mas-
Lithofacies code symbols used in this study

\begin{tabular}{|l|c|}
\hline Code & Genesis \\
\hline SG & sediment gravity flow \\
\hline TU/SS & turbidity current and/or suspension settling \\
\hline SF & sheet flow \\
\hline SW & slope wash \\
\hline GP & gravelly erosional pavement (fluvial/aeolian) \\
\hline SU & sandy upper plane bed \\
\hline
\end{tabular}

sive structure, thin beds with sheet geometry, lack of erosional contacts between the beds.

UNIT II

Matrix-supported diamicton $\operatorname{DMm}\left(\mathrm{m}_{1}\right)$ is grey and massive (Figs. 34 and $5 \mathrm{~A}$ ) The matrix consists mostly of clay. tains gravels ansingle boulders, up to $35 \mathrm{~cm}$ across (Fig.4) It occurs in the form of three beds, 5-25 cm thick, separated by silty sands (unit III). In the proximal part, the diamicton beds are close-packed (compact) while in the distal part they are loosely packed, plastically stretched, and occur in the form of lobes and flow folds. These diamictons pinch out in distal direction, with the exception of the lowermost bed, which forms a syncline and interfingers with deformed massive silty/sandy deposits (unit IV). Ductile deformation occurs in the top part of unit II. The upper bed of the clayey diamicton is discontinuous. It is composed of irregular fragments. Diapiric forms and folds occur in this zone. Thickness of the deformed deposits is small (about $0.3-1.0 \mathrm{~m})$.

In the lower bed, the long axes of clasts and boulders (megaclast) are parallel to the direction of local material transport. Two single megaclasts are visible, i.e. of granite (Fig. 4A, B) and detrital limestone (Fig. 4C, D). The granite boulder has stoss-lee form and there is a prow in front of it (Fig. 4B). Its bottom part, partially plunged into the diamicton, is angular in contrast to the smoothed and rounded upper surface. Fresh traces of breaking off and crushing are visible on the proximal wall of the boulder. The limestone boulder is elongated, flat topped, with polished upper and lower surfaces (facetted clast) on which elongated grooves with rounded edges are visible (Fig. 4D).

Microscopic analysis reveals poorly sorted material with numerous skeleton grain $\$$ (Fig. 5B and Table 3 - sample 1). The silt grains are predominamtty angular to subalar in shape, while the larger sand grains are more edge-rounded. The matrix is composed of silt grains with clay material. Clay-rich zones are visible in the matrix. The voids are mainly of planar void type. The matrix has clear marble structure, where the deposit consists of e rाuाmber of spletrical pggregates that behave like ball bearing $\$$ (Van der Meer, 1993; Fig. 5C). There are abundant flow tail and rotation structures (Fig. 5D), small water-escape structures and grain clusters (with crushed grains in places; Fig. 5E). Distinct planar shear structures have not been found. only indistinct lineation is visible in the matrix. Insepic plasmic fabric generally dominates but, in places, the clay-rich zones form coatings around the skeleton grains (poorly developed skelsepic plasmic fabric). A certain orientation is visible along the direction of bedrock inclination. Long axes of coarser skeleton grains are similarly oriented along this direction, forming flow tail microstructures in places. Clay-rich zones and voids 

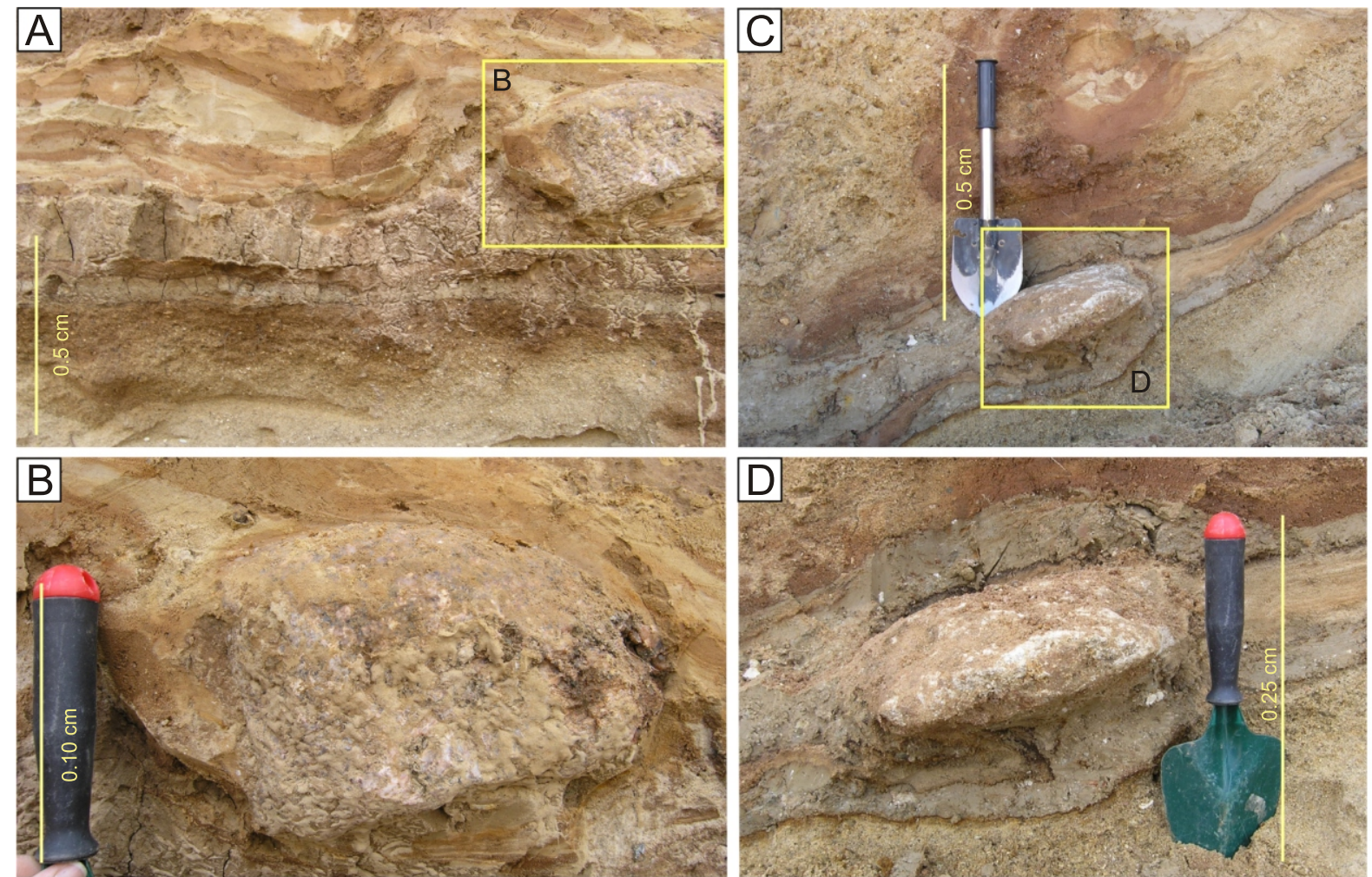

Fig. 4. Megaclasts in the lower part of the clayey diamicton (unit II):

A - granite, B - limestone, C - stoss-lee forms and prow in front of the granite boulder-clast,

D - typical wear patterns on the actively transported limestone-clast

decrease in amplitude along the direction of bedrock inclination.

$\mathrm{Fe} / \mathrm{Mn}$ staining is frequent.

Interpretation. The occurrence of flow structures in the disal parts of the diamictons indicates that the material released rom melting ice was redeposited in the form of flows (cf. Evans and Hiemstra, 2005). Clayey matrix of the diamictons and the pccurrence of lobes and flow folds are diagnostic for sediments deposited as a result of dense, cohesive flow named flow (Nemec and Steel, 1984), high-strength flow (Shultz, 1984), rue mass flow (Pierson, 1985), i.e. slow flow occurring as nostly laminar movement. It is also confirmed by depositional contact between the diamicton and the underlying series of sandy/gravelly deposits (Kasprzak and Kozarski, 1984; achniet et al., 1999).

The features of the megaclasts indicate the processes of crushing and abrading occurring in a subglacial traction zone e.g., Boulton, 1978; Krüger, 1984; Evans et al., 2006; Benn and Evans, 2010), or transport in deforming layer (Benn and Evans, 1996). However, the situation of megaclasts in the studed deposits (on the surface of thin diamicton bed) indicates that hey were melted out at the ice base and transported over a short distance on the flow surface. Cohesive flows are characerized by high competence (Pierson, 1985). Transport and stapilization of the granite megaclast is recorded as a visible prow n the diamicton in front of the boulder. In the subglacial zone, the occurrence of similar prows indicates the ploughing of the soft bed (e.g., Boulton, 1978; Krüger, 1984; Evans et al., 2006).

Deformation structures occurring in the middle and upper peds of the clayey diamicton are probably of complex origin. They are postdepositional, load-cast structures due to fast aggradation of the overlying sandy/silty diamicton (unit VI) and subsequent subsidence resulting from permafrost thaw. The grain size contrast of sandwiched deposits and periodically water-saturated ground in periglacial conditions favoured the development of these structures (cf. Goździk, 1973; Vandenberghe, 1988). Deformation of the diamicton's upper bed could not be caused by seasonally advancing ice sheet because diapiric forms could not keep a vertical position under subhorizontal pressure exerted by it. They all would have been bended (cf. Ruszczyńska-Szejnach, 1998).

Microscopic analysis does not allow unequivocal genetic interpretation of the deposit. The observed coincidence of microstructures may indicate both cohesive flow and till formed in a submarginal zone.

Turbate grain arrangement is indicative of rotational movements of grains in subglacial shear regime (Van der Meer, 1993, 1997; Hiemstra, 2001; Hiemstra and Rijsdijk, 2003). However, the turbates may only then be considered diagnostic for a subglacial till where they are closely related to planar shear structures. Distinct planar shear structures are absent in the studied deposits. This fact indicates that these deposits well represent a mass movement deposit, in which flow was the predominant deformation mode (cf. Hiemstra and Rijsdijk, 2003). Turbate structures are found in clayey deposits of debris flow. Formation of these structures in such deposits is explained by mixing during flow transport (Lachniet et al., 2001; Menzies and Zaniewski, 2003; Phillips, 2006). However, it cannot be excluded that the deposit is a till formed in a submarginal environment, under seasonally changing climate conditions. The shear indicators were not preserved owing to superimposed and possibly younger frost processes as well as processes related to pore-water movement (cf. Evans and Hiemstra, 2005).

Marble-bed structure may result from an initial subglacial compression, by the gradual upward progression of 

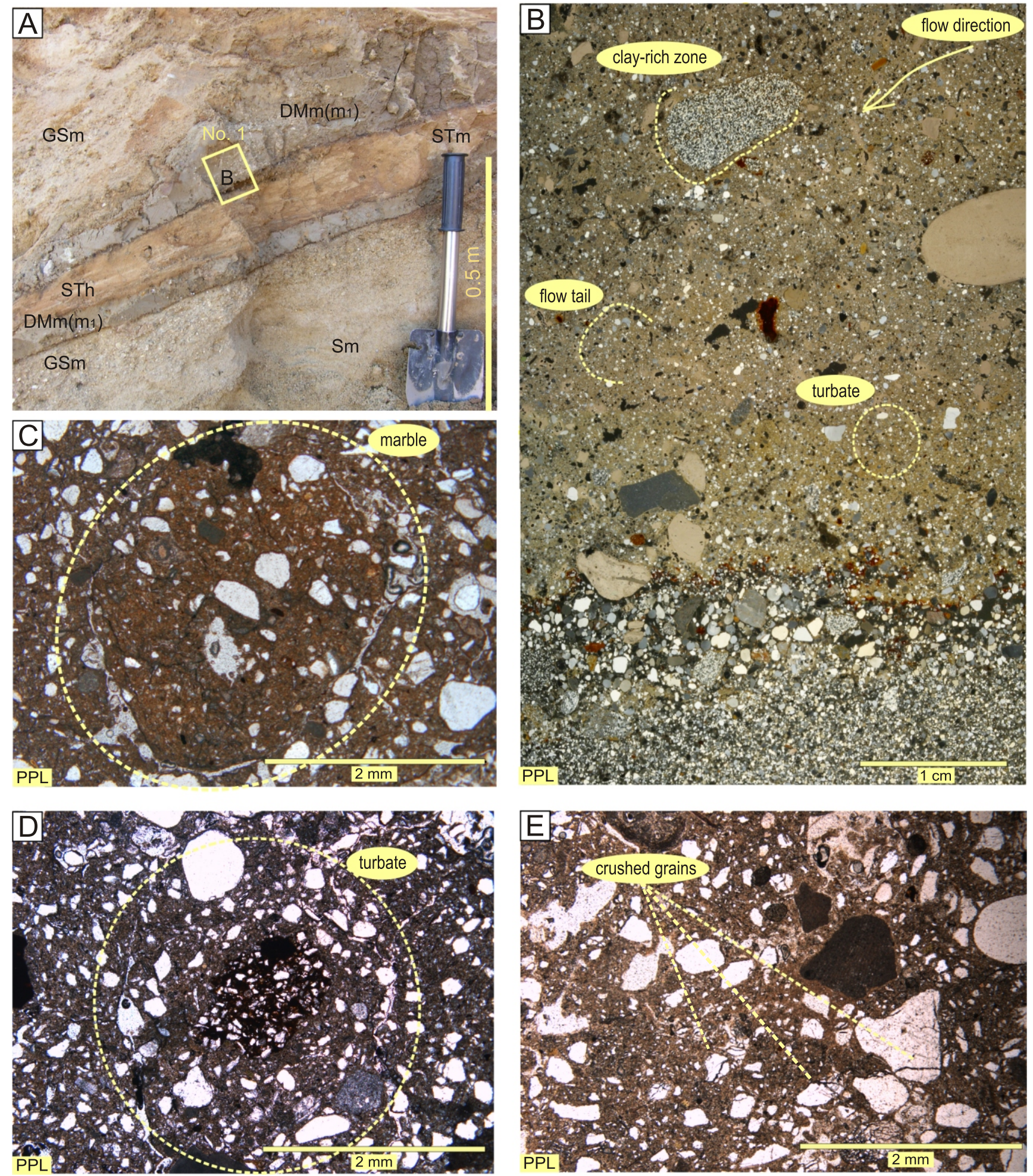

Fig. 5. Diamicton with clayey matrix (sample 1/unit II; Table 3)-micromorphological images

A - sample location for microstructural research; B - poorly sorted material with numerous skeleton grains and clay-rich zone, visible orientation in the distribution of skeleton grains and voids - along the flow direction; C - matrix with marbled appearance; D - turbate structure; $\mathbf{E}$ - grain cluster with crushed grains; PPL - plane polarised light 
Summary of micromorphological characteristics in this study

\begin{tabular}{|c|c|c|c|c|c|c|c|c|c|c|c|c|c|c|c|c|c|c|}
\hline \multirow{2}{*}{$\begin{array}{l}\text { 䓂 } \\
\frac{\Phi}{0} \\
\frac{\Phi}{\tilde{E}} \\
\infty\end{array}$} & \multirow[b]{2}{*}{ 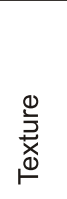 } & \multicolumn{2}{|c|}{$\begin{array}{l}\text { Skeleton } \\
\text { roundness }\end{array}$} & \multirow[b]{2}{*}{$\begin{array}{l}0 \\
\frac{0}{0} \\
\frac{\pi}{0} \\
\frac{0}{0} \\
\frac{0}{\Sigma}\end{array}$} & \multirow[b]{2}{*}{ 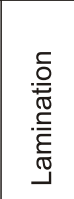 } & \multicolumn{2}{|c|}{ Voids } & \multicolumn{9}{|c|}{ Deformation structures } & \multirow[b]{2}{*}{$\begin{array}{l}\text { Plasmic } \\
\text { fabric }\end{array}$} & \multirow{2}{*}{ 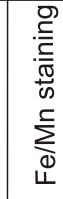 } \\
\hline & & 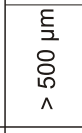 & 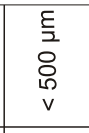 & & & 은 & $\stackrel{2}{2}$ & 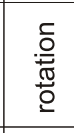 & $\begin{array}{l}\frac{0}{0} \\
\frac{0}{\mathrm{~N}} \\
\text { E⿱ }\end{array}$ & 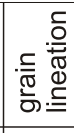 & 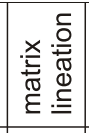 & 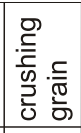 & 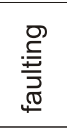 & $\begin{array}{l}\text { 음 } \\
\text { 흥 }\end{array}$ & $\begin{array}{l}\frac{0}{0} \\
\frac{0}{0} \\
\frac{0}{2}\end{array}$ & 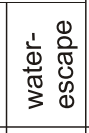 & & \\
\hline $1 / / I$ & M & $\mathrm{R}$ & A/SA & $\mathrm{F}$ & & - & $\mathrm{PI}$ & $\bullet$ & $\bullet$ & & - & - & & & & - & $\begin{array}{l}\text { insepic } \\
\text { skelsepic }\end{array}$ & $\bullet \bullet$ \\
\hline $2 / I I I$ & $\mathrm{C} / \mathrm{F}$ & SA/R & SA/R & $\mathrm{F}$ & $\bullet \bullet$ & $\bullet$ & $\begin{array}{l}\mathrm{Ve} \\
\mathrm{Vu} \\
\mathrm{Pa}\end{array}$ & & & & & & & & $\bullet$ & $\bullet$ & & $\bullet$ \\
\hline $3 / \mathrm{IV}$ & $\mathrm{C} / \mathrm{F}$ & SA/R & SA/R & D & $\bullet$ & $\bullet$ & $\begin{array}{l}\mathrm{Ve} \\
\mathrm{Vu} \\
\mathrm{Pa}\end{array}$ & & & & $\bullet$ & & • & $\bullet$ & $\bullet$ & $\bullet$ & & - \\
\hline $4 / \mathrm{VI}$ & M & $\mathrm{R}$ & SA & $\mathrm{v}$ & & $\bullet \bullet$ & $\begin{array}{l}\mathrm{Vu} \\
\mathrm{Pa} \\
\mathrm{PI}\end{array}$ & $\bullet$ & & $\bullet$ & $\bullet \bullet$ & & & & $\bullet$ & $\bullet$ & $\begin{array}{c}\text { silasepic } \\
\text { argillasepic }\end{array}$ & •.• \\
\hline $5 / \mathrm{VIII}$ & C & $\mathrm{R}$ & A & $\mathrm{v}$ & & $\bullet \bullet$ & $\mathrm{Pa}$ & & & & & - & & & & & & $\bullet$ \\
\hline $6 / 1 X$ & $\mathrm{~F}$ & & & & & $\bullet$ & $\mathrm{PI}$ & & & & & $\bullet$ & & & & & vosepic & $\bullet \bullet$ \\
\hline
\end{tabular}

The number of circles represents the relative strength and abundance of features from absent (no circles) to abundant, well-developed (three circles); key to texture: C - coarse, F - fine, M - medium; key to skeleton roundness: R - rounded, SA - subangular, A - angular; key to microfabric: $\mathrm{F}$ - flow parallel, $\mathrm{V}$ - vertical, D - deformation parallel; key to voids type: $\mathrm{Ve}$ - vesicles, $\mathrm{Vu}$ - vugs, PI - planar voids, $\mathrm{Pa}$ - packing voids

subhorizontal shears, brecciation and rotation of aggregates (Van der Meer, 1993). This view is substantiated by the in situ production of crushed grains (Hiemstra and Van der Meer, 1997). Marble-bed and turbate structures are formed under different subglacial conditions. In the opinion of some researchers, the zone of shearing can change from the marble-bed coniguration to one that consists of rotational structures and a skelsepic plasmic fabric (Van der Meer et al., 2003). There is also a view that marble-bed and turbate structures are formed n reverse order. The process of marble-bed formation destroys urbate and linear structures by breaking them apart, when shear is the dominant deforming factor, and water pressures are not high (Kilfeather et al., 2008).

Marble-bed structure is also described and even considered as diagnostic for debris flow deposits (Menzies and Zaniewski, 2003). Crushed grains are also found in both debris low deposits (e.g., Bertran and Texier, 1999) and subglacial till. In the case documented by Hiemstra and Van der Meer (1997), the co-occurrence of marble-bed structure and in situ crushed grains is considered as resulting from pulsed water movement with alternating wet and dry conditions. Such co-occurrence may indicate the formation of deposits at the contact with the glacier.

Small water-escape structures record pore-water movement - when the deposit became drained and consolidated.

UNIT III

The above-described beds (unit -1) are separated by silty sand interlayers (STm; unit III; Figs. 3 and 6A). These interlayers have a varying thickness (from 5 to $15 \mathrm{~cm}$ ) and horizontal extent reaching over $3 \mathrm{~m}$. They partially surround the megaclasts. The layers separating the lower beds of the diamicton (unit II) occur in places as thin (up to $5 \mathrm{~cm}$ thick) very compact lenses. Their thickness increases (to $35 \mathrm{~cm}$ ) and compactness of material decreases upwards. The layer underlying the upper bed (occurring in diapiric forms) of the diamicton (unit II) is also deformed.

Microscqpic analysis reveals lamination in the deposits (FIg. GB and Iable 3 -sample 2). The alternating laminae of diamicton, sttt and sanctare often sep qrated by erosional surfaces. The contacts between the diamicton and silt layers are loaded in places (Fig. 6C). The matrix-supported massive diamicton is characterized by a high dlay content. The grains are subangular to rounded in shape. Pebble structures occur. The sandy laminae are locally graded. Horizontal lamination is visible in places in the silty laminae (1h). Fissures and voids have been found in this deposit. Voids in the diamicton are mainly vesicles and vughs, while packing voids occur in sandy and silty laminae. Numerous water-escape structures (dishes and pillars) are noteworthy (Fig. 6D, E). Fe/Mn staining is found.

Interpretation. The interlayers of distinctly silty sands (intersurge layers - sensu Nemec and Steel, 1984) are interpreted as derived from fluvial flow, usually of sheet flow type (Lawson, 1982; Zieliński, 1993) covering the entire surface of debrite. During freezing, the pore-water is squeezed off and forms a shallow and quite fast stream (Lawson, 1982; Zieliński, 1993; Ruszczyńska-Szejnach, 1998). The analysed deposits represent the distal part of the flow so the thickness of debrites decreases and that of sediments deposited by sheet flows increases along the slope inclination.

Visible under microscope lamination is a record of variable flow energy. The diamicton laminae were formed by erosion of material from the bedrock and short initial transport (see Steel and Thompson, 1983; Nemec and Steel, 1984). The occurrence of pebble microstructures indicates erosion of the bed- 

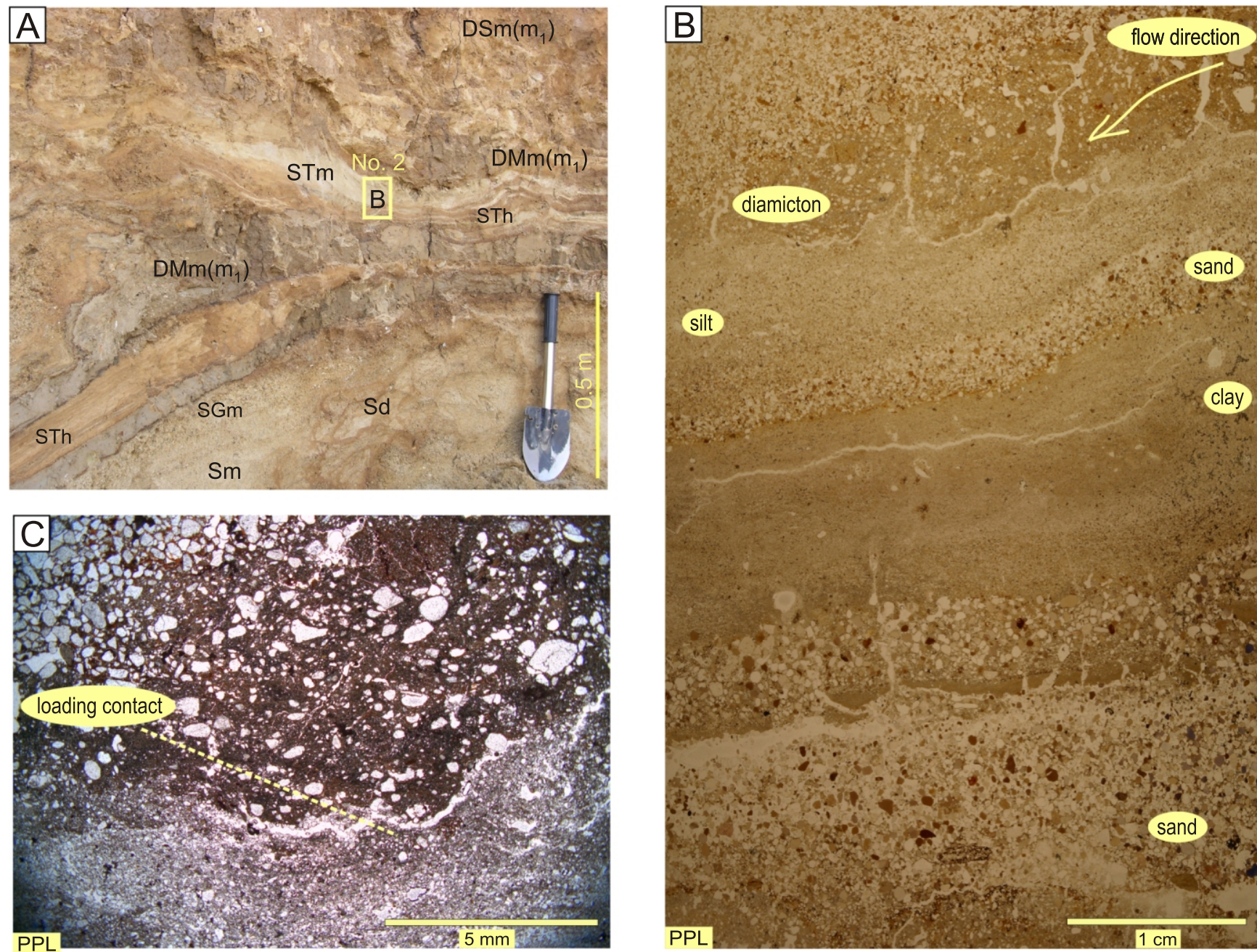

PPL

$1 \mathrm{~cm}$
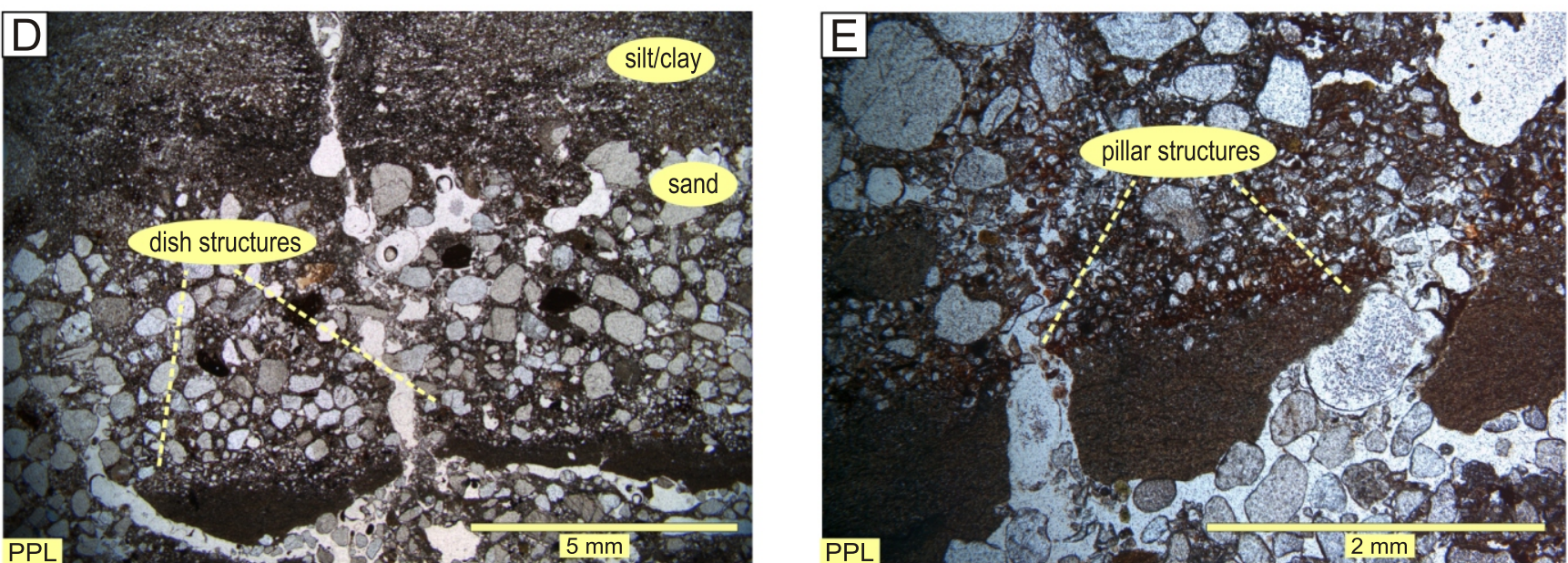

Fig. 6. Silty sand layers (sample 2/unit III; Table 3) - micromorphological images

A - sample location for microstructural research; B - lamination (alternating laminae of diamicton, silts and sands are often separated by erosional surfaces, numerous water-escape structures); C - loaded contact between clay-rich diamicton and silt layer; D - dish-type water-escape structure and horizontal lamination in silty/clayey layer; $\mathbf{E}$ - pillar-type water-escape structure 

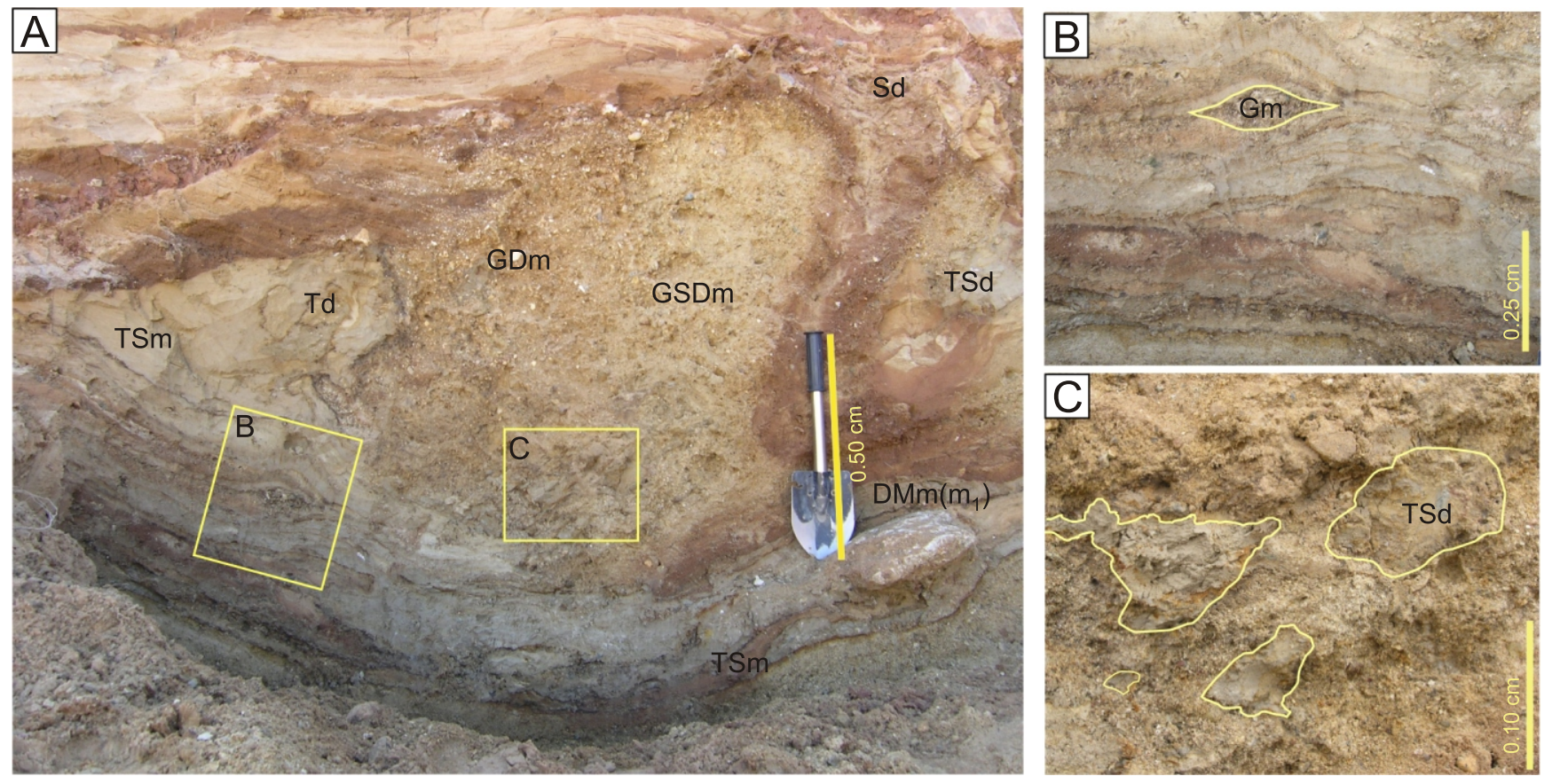

Fig. 7A - synclinally bent complex of silty/sandy deposits (unit IV) and detached lump of diamictic gravels and gravelly sands (unit V; see Fig. 3); B - gravelly lens (interpreted as being formed from the material transported to the lake as a frozen block released from the melting ice base) visible in the silty/sandy complex; $\mathrm{C}$ - silty inserts, irregular in shape, visible in the detached lump (interpreted as the result of silt deposit deformation caused by the encroachment of flows into the lake)

rock. The massive sands are interpreted as the records of high-energy flow - deposited from supercritical flow in the upper-stage plane-bed conditions (cf. Nemec et al., 1980; Zieliński and Loon, 1996). The normal grading indicates a gradual decrease of flow energy. The silty laminae with horizontal lamination were deposited by low-energy flows. The escape microstructures are the traces of pore-water movement during draining and consolidation of deposit, probably under the load of overlying deposit.

Deformation structures visible in the upper layer are of load type. They developed as a result of the deposition of the overlying sandy diamicton (unit VI), similarly as the above-described deformations of the upper part of unit II. The varying thickness and compactness of the silty sand layers (unit III) may be also related to the overlying deposit load. However, it cannot be excluded that the very compact lower layers were formed in a submarginal environment, under the pressure of ice masses during their small advance. In such conditions the deposits formed as sand pockets are stretched and attenuated, and transformed into sand sheets and stringers (Kessler et al., 2012).

UNIT IV

Silty/sandy complex occurs within the deposits of unit I and interfingers with the diamicton of unit II (Figs. 3. 7A find 8A). It consists of synclinally bended, fine sandy silt (4Sm) and silty (Tm) laminae. Gravelly lenses $(\mathrm{Gm})$ are visible in places (Fig. 7B). Massive silts (Fm) occur in the top part.

copic analysis indipates strong deformation of the deposit (Fig. 8B and Table 3 - sample 3). A banding structure is found-deformed layers of silt and clay (Fig. 8C). Disrupted frag- ments of laminae are visible (Fig. 8D). The contacts between these deposits are sharp, in places with the zones of clay concentration with common traces of deformation. Fold deformations (Fig. 8E), matrix lineations and small faults occur. Few traces of clay displacement and water-escape structures are found.

Interpretation. Deposits of the silty/sandy complex are a record of an ephemeral lake, in which settlement from suspension took place. Gravelly lenses were formed from the material transported to the lake as frozen blocks released from the melting ice base. Massive silts are interpreted as a record of turbidity currents triggered in this lake by mixing and thinning of cohesive debris flows (unit II; cf. Mohrig et al., 1998; Marr et al. 2002; Talling et al., 2004).

UNIT V

The detached gravelly/sandy lump, oval in shape, laterally contacts with the silty/sandy complex (unit IVE Figs. 3 ind TA). It is composed of diamictic gravels (GDm) and diamictic sandy gravels (GSDm). The deposits are massive in structure and have sandy-clayey matrix. A higher content of fines s the only difference between these deposits and the gravels $(\mathrm{Gm})$ and sandy gravels (SGm) of unit I. The detached lump contains fragments of silt deposit from the top part of unit IV (Fig. 7C), and occasional clasts of clayey diamicton (unit II).

Interpretation. Diamictic gravels (GDm) and diamictic sandy gravels (GSDm) may have been deposited by subaerial debris flow (cf. Kasprzak and Kozarski, 1984; Krüger and Kjær, 1999; Zieliński, 2003). The development of these flows and their encroachment int the take caused the devetopment of deformations at the contact with lacustrine deposits (see unit IV) - 

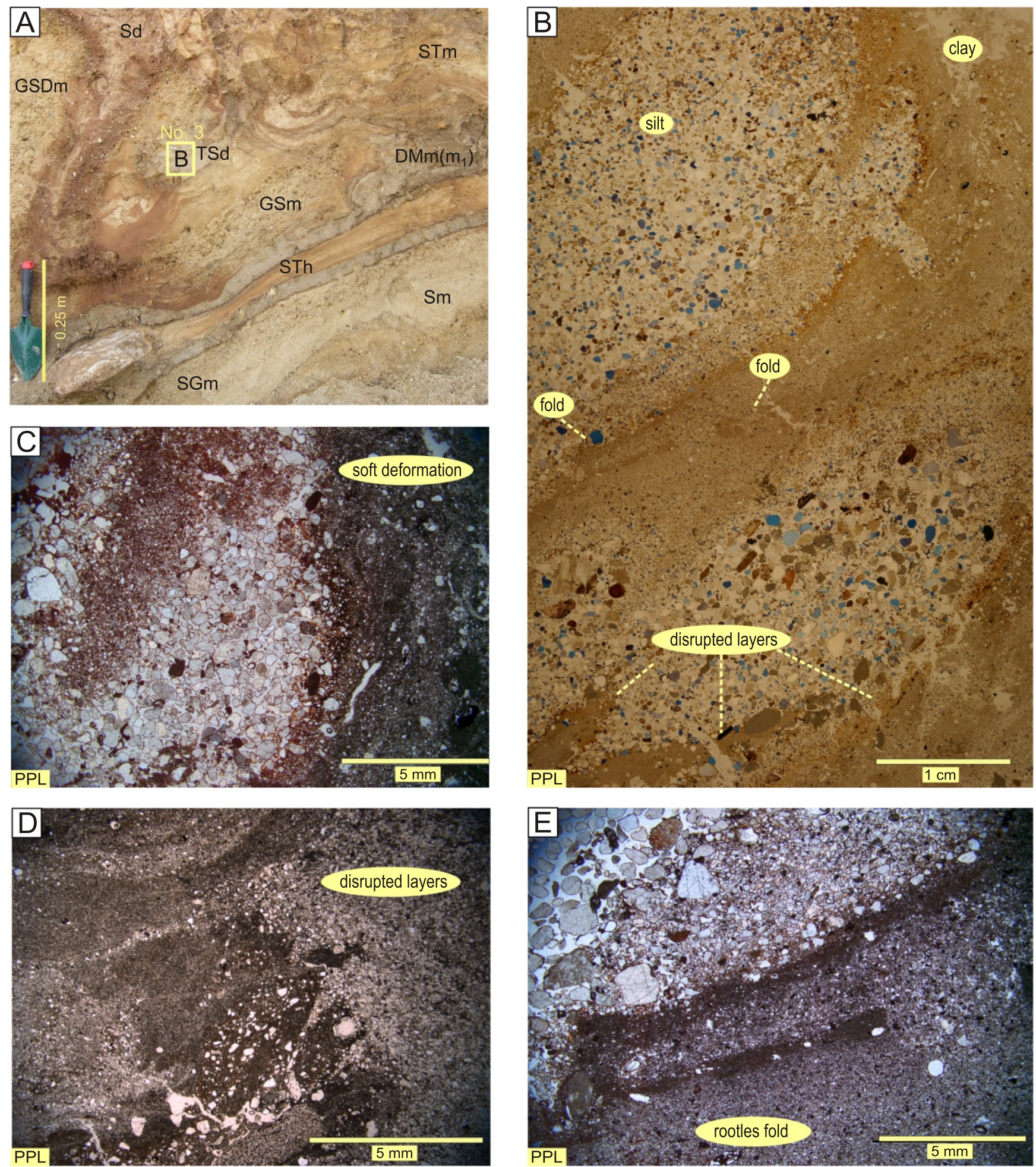

Fig. 8. Silty/sandy complex (sample 3/unit IV; Table 3)- micromorphological images

A - sample location for microstructural research; B - deformed layers of silt and clay with sharp contacts, and zones of clay concentration with common traces of deformation, fold structures and disrupted fragments of laminae; C - soft deformation in the form of banding structure consisting of vertical silt and clay laminae; D - disrupted silt and clay layers; E - fold deformation in a clay layer 
i.e. (1) the formation of a fold as a result of compression that can occur during debris flow deposition (Nemec, 1990), (2) synclinal bending, disruption and pushing of silty/sandy laminae, and (3) formation of silty and clayey diamicton inserts in the lump.

UNIT VI

Matrix-supported diamicton $\mathrm{DSm}\left(\mathrm{m}_{1}\right)$ is brown, $1.0-1.5 \mathrm{~m}$ thick. Sandy-silty fraction predominates in the matrix (Figs. 3 and 9A). The diamicton is massive in structure, with discontinupus streaks in places. These are silty layers, up to $2 \mathrm{~cm}$ thick, parallel to the inclined basal surface of the diamicton, which ocfur mainly in the lower part of the diamicton. The long axes of lasts are transverse to the movement direction. However, they commertically orientated in the distal part of the deposits (Fig. 3). Coarsening-up texture occurs in the lower part of the diamicton. Strongly weathered (disintegrated in to grains) ragments of Scandinavian rocks, with deformed shapes, are jisible in the diamicton. The contact with the diamicton of unit II $s$ depositional and loaded (see description of unit II)

Microscopic analysis reveals poorly sorted material with single skeleton grains (Fig. 9B and Table 3 - sample 4). The silt grains are predominantly subangular, while the sand grains are ounded. The matrix is composed of silt and clay material. Numerous clast-supported silty/sandy domains and domains with llayey matrix occur in the deposit (Fig. 9B). The larqest clasts are vertically oriented. The deposits are characterized by great microporosity. The voids are vugs, packing voids (in pilty/sandy lomains) and planar voids or fissures. Pebbles are quite numerous. Both grain and matrix lineation (Fig. 9C), and rotational structures (in the domains with clayey matrix; Fig. 9D) are found $\mathrm{n}$ the deposit. Small water-escape structures also oфcur. Plasmic fabric pattern has not been observed. It can b申 said that argillasepic plasmic fabric occurs in places, and elsewhere silasepic fabric is observed. Packing voids frequently contain precipitated iron or manganese (Fig. 9E).

Interpretation. Grain-size distribution of matrix (high content of sand and a low proportion of fine fractions) and massive structure indicates that the deposit is of cohesionless debris flow type (Eyles, 1979; Nemec and Steel, 1984; Zieliński and Loon, 1996; Dasgupta, 2003). It is a transition type between debris flow and grain flow - according to the classification by Shultz (1984) it is clast-rich debris flow. Similar flows are also called coarse-grained debris flows. The laminae within the massive deposit are not a depositional but a deformational structure resulting from intense shearing and laminar flow (sheared sediment; Postma et al., 1983). Transverse orientation of clasts' long axes is typical of the distal parts of gravity flows (similarly as in slope deposits; Blikra and Nemec, 1998), while vertical orientation of clasts indicates a strongly water-saturated environment where elongated boulders slowly sink into the moving clayey mass (cf. Ruszczyńska-Szenajch, 1998). The coarsening-up tendency, visible in the basal part of the diamicton, should be related to high shear stress in the flow "foot" (cf. Nemec and Steel, 1984). Deformation of shapes of the weathered Scandinavian boulders is a record of postdepositional modification of the deposit in periglacial conditions.

Microscopic analysis confirms that the deposit was formed as a result of strongly water-saturated flow. It is indicated by great microporosity and the occurrence of vughs and planar voids (cf. Kilfeather et al., 2008). Domains, pebbles and rotational structures are frequent in debris flow deposits (Lachniet et al., 2001; Menzies and Zaniewski, 2003; Phillips, 2006). The lack of plasmic fabric pattern may be the result of relatively low-stress depositional conditions. Silasepic and argillasepic plasmic fabric can be found in flow tills (Van der Meer, 1997 Menzies and Zaniewski, 2003). Deposition from water-saturated flow is also indicated by the lack of deformation (related to the flow development) in the underlying deposits (cf. wet-typ flow deposit; Lachniet et al., 1999), in which only load-type de formation occurs, i.e. vertical diapiric forms without traces of horizontal displacement.

\section{UNIT VII}

A gravelly pavement (Gm; unit VIla; Eig. 3) truncates the deposits of units IV and V. Gravels are strongly cemented with the iron-clayey cement. The long axes of gravels are oriented obliquely or parallel to the accumulation surface.

The gravelly pavement is covered with sandy/clayey breccia (unit VIIb). It is a clast-supported bed, 0.5-0.65 m thick. Irregular, angular, fine-sand clasts are $0.25-0.40 \mathrm{~m}$ in size. Sand and gravelly sand shows low-angle cross-stratification (SI) and horizontal stratification (Sh). The breccia matrix is clayey sand impregnated with iron oxides and hydroxides (limonite and hematite).

Interpretation. Internal structure of sandy and gravelly sand clasts (SGI, SI, Sh) suggests a stream flow/river origin of sands, at the transition from subcritical to supercritical flow (upper-stage plane-bed; Zieliński, 1998). These are channel de posits of sand-bed braided river/stream. The gravel layer $(\mathrm{Gm})$ occurring at the bottom of the deposits is interpreted as an erosion/deflation pavement recording fluvial/aeolian processes. The functioning of channel flow created good conditions for thermoerosion processes (Murton and French, 1993; French, 1996). The angular shape of sandy clasts indicates disintegra tion of the sandlayers in the conditions of frozen bedrock. Both desiccation and frost action occurred at that time. Sandy clasts were dislocated at a short distance only. The clasts were cemented by clayey-iron cement as a result of infiltration of colloidal clay and iron compounds.

\section{UNIT VIII}

Unit VIII is represented by sand filling fissure structure. This fissure, 1. $\mathrm{m}$ deep and up to $0.2 \mathrm{~m}$ wide (Figs. 3 and $10 \mathrm{~A}$ ), developed in the boundary zone of the desits different grain-size distr bution - diamictons with clayey matrix (unit II), silty sand layers (unit III), detached gravelly/sandy lump (unit V) and diamictons with sandy matrix (unit $\mathrm{VI}$ ). The fissure is generally wedge-shaped. The upper part of the fissure is wider and funnel-like, and the narrow lower part cuts the detached gravelly/sandy lump. The whole fissure is filled mostly with fine sand, which is macroscopically identical to the brecciated sands occurring over the fissure. The fissure walls are accentuated by rust brown colour of deposits, which occur also below the fissure, down to the contact with the clayey diamicton of unit II.

Microscopic analysis revealed that it is grain-supported deposit (granular microstructure) composed mostly of sand-sized quartzgrains accompanied by silt and gravels (Fig. 10B, C and Table 3 - sample 5). Sand grains are rounded, while silt grains are angular. Grushed grains are also found. The deposit is strongly porou $\$$, with packing voids. Most grains are vertically oriented. In places, under gravel grains, concave sandy laminae are visible (Fig. 10C). Bridged grain microstructure is found, i.e. the occurrence of clayey-ferruginous concentrations/bridges between grains (Fig. 10B).

Interpretation. Formation of this fissure can be related to postdepositional gravitational processes so it may be consid- 

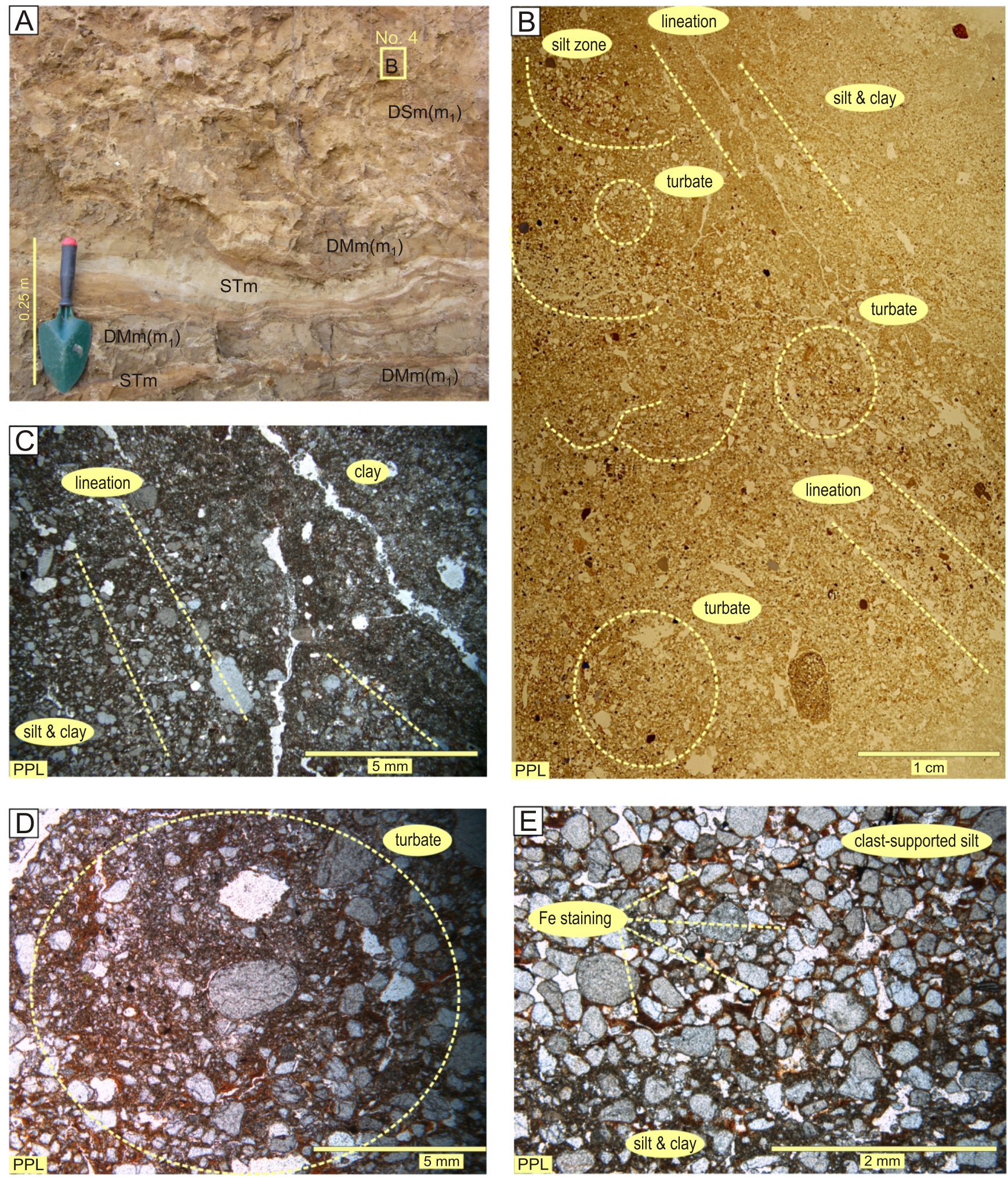

Fig. 9. Diamicton with sandy matrix (sample 4/unit VI; Table 3) - micromorphological images

A - sample location for microstructural research; B - poorly sorted material with single skeleton grains (zones of clast-supported silty/sandy material and zones with clayey matrix, grain lineation, matrix lineation and turbate structures are visible, the largest clasts are vertically oriented); C - grain lineation visible at the contact of silty/sandy and clay domains; D - turbate structure in the zone of silt with clayey matrix; $\mathbf{E}$ silty/sandy zones with packing voids, which contain precipitated iron or manganese 

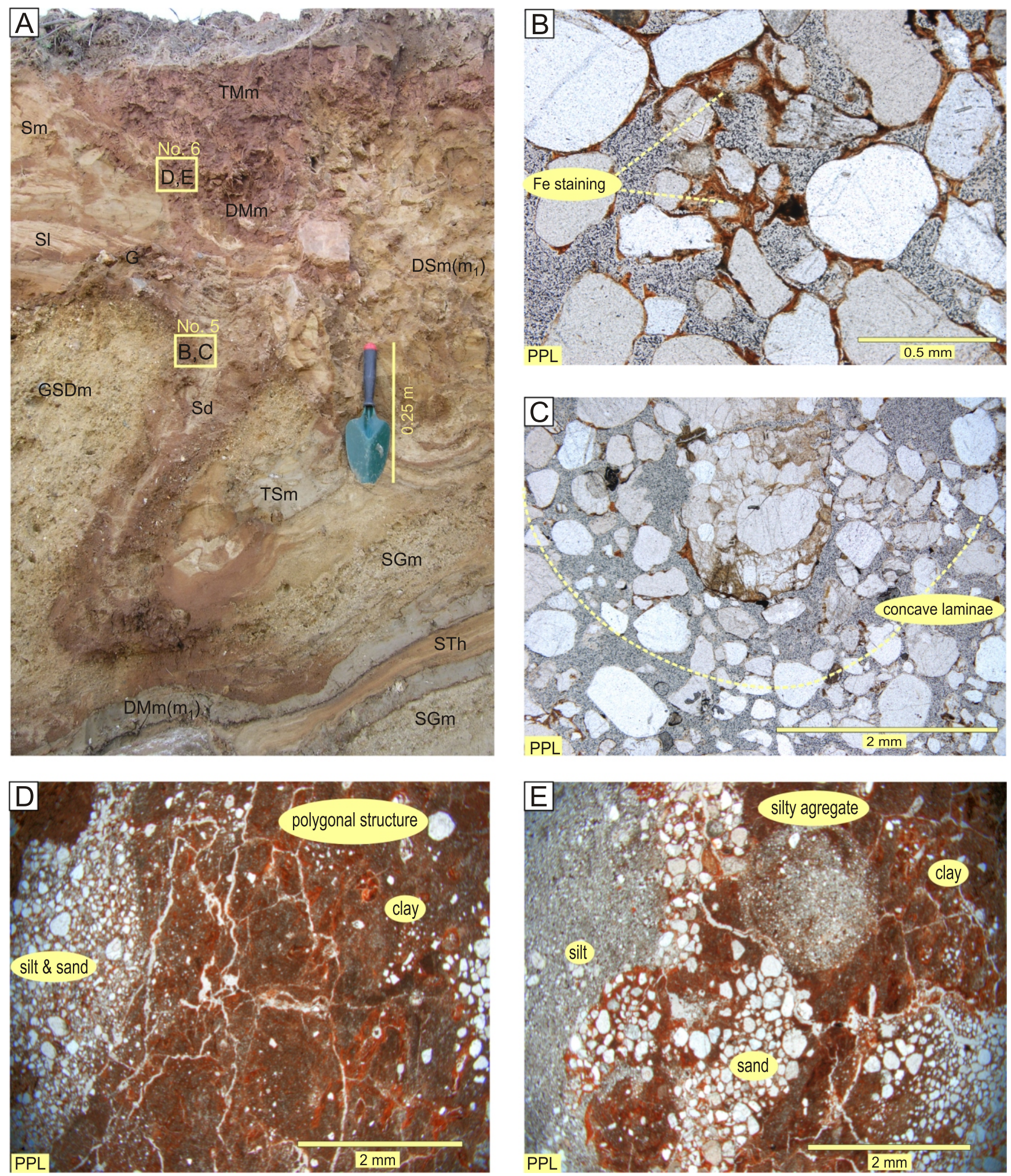
Fig. 10. Sand filling a fissure structure (sample 5/unit VIII; Table 3) and silty/clayey diamicton (sample 6/unit IX; Table 3) -

A - samples location for microstructural research; B - grain-supported, strongly porous deposit composed mostly of sand-sized quartz grains accompanied by silt and gravels (clayey-ferruginous concentrations/bridges between grains); C - vertically oriented grains and concave laminae under gravel grains; D - sharp erosional contact of sand with strongly ferruginous (cherry) clays (vertical orientation of deposits, polygonal microstructure with a dense net of small fissures occurs in the clays); $\mathbf{E}$ - ball-shaped silty microaggregate in clay 
ered as a gravitational fissure. However, it cannot be excluded that the fissure was formed with the participation of frost processes. The microstructure of the infilling - vertical orientation of grains and the occurrence of concave sandy laminae under gravel grains - indicates avalanching of deposits in a dry, cold environment (cf. Bertran and Texier, 1999). Such fissure filling is typical of wedge casts with primary mineral infilling, formed as a result of therm fl contraction (Goździk, 1973). The occurrence of bridged grain microstructure in the sand filling the fissure, as well as rust brown colour of deposits in the fissure walls and under it, indicate postdepositional changes of humidity resulting in ground cracking and infiltration of colloidal clay and iron compounds.

\section{UNIT IX}

Matrix-supported diamicton with silty/clayey matrix (DMm) is red-brown (cherry; Figs. 3 and 10A). It is mostly massive in structure, locally with visible silty/sandy thin lenses. It covers the erosional, wavy surface cutting the underlying deposits (unit $\mathrm{VI}$, partially unit VIIl; Fig. 3). At thle bottoms of deeper erosional dissections, the diamicton is characterized by a high content of gravels. Their amount decreases upward the dissection infillings, and muddy (clayey) silts (TMm) occur there.

The contact of this depqsit and sandy/clayey breccia (unit VIlb) has been examined under microscope (Fig. 10D, E and Table 3 -sample 6). It is a sharp, erosional contact, locally with ball-shaped silty microaggregates (Fig. 10E). The clay is strongly ferruginous and exhihits a polygonal microstructure with a dense net of small fissures (Fig. 10D). Vosepic plasmic fabric is found in places - plasma layers are visible on the fissure walls.

Interpretation. Diamicton is a wash-slope deposit formed by high-energy flow with a great concentration of sediment. Its deposition was preceded by linear erosion. The occurrence of gravels at the dissections' bottoms indicates that material, which was earlier transported in suspension, was abruptly deposited and become dragged material. The ball-shaped microaggregates, visible under microscope, are typical of deposits formed by slope wash processes in clayey-silty material (Mücher and Ploey, 1977). The polygonal microstructure was as atesitional processes related to pore-water movement and deposit draining. The vosepic plasmic fabric was probably formed during pedogenesis. Their sedimentary structure (lamination) was partially blurred by pedogenesis.

\section{PALAEOGEOGRAPHICAL INTERPRETATION}

Interpretation of depositional environment. The deposits (units I-VI) form a lithofacies complex with the following features indicating its deposition in a glaciomarginal environment: (1) the predominance of sediment-gravity flow deposits deposjed (subaerially and subaqueously) by cohesive and cohesionless debris flows (flow tills, diamictic gravels; units II, $\mathrm{V}, \mathrm{VI}$ ) as well as turbidity currents (silty/sandy complex; unit IV), 2) a small proportion of well-sorted deposits (gravels and sands; units I, III), (3) the interfingering/alternating of sediment-gravity flow deposits and glaciofluvial (in boreholes), waterlain deposits (cf. Boulton, 1971; Lawson, 1979, 1982; Ruszczyńska-Szenajch, 1982; Johnson, 1990; Zieliński, 1992, 2003; Kozarski, 1995; Zieliński and Loon, 1996; Krzyszkowski and Zieliński, 2002; Kasprzak, 2003; Terpiłowski, 2003, 2008; Pisarska-Jamroży, 2006).
Deposits of units VII-IX were formed in a periglacial environment. They were deposited in erosional dissections (units VII, IX) and gravitational-cryogenic fissures (unit VIII). A more detailed description of depositional conditions was possible based on the analysis of their textural features. In the case of sandy breccia (unit VIIb), internal structure of sandy clasts confirms a fluvial (channel) origin of sands, while the analysis of heavy minerals - selective enrichment in garnets (Ludwikowska-Kędzia, 2013) - indicates an aeolian/fluvial environment (Mycielska-Dowgiałło, 2007). Textural features o quartz grains - roundness and surface morphology - indicate an aeolian environment. These sands are recognized as fluvio-aeolian deposits (Kasse et al., 2003). Similar deposits have been interpreted as fluvioperiglacial deposits (cf Łyczewska, 1971). The accumulation of these deposits occurred in a river valley where the alluvia were supplied with wind-transported grains. Dunes and cover sands were the source areas of aeolisated sands, which were activated by denudation and fluvial processes (cf. Woronko, 2012). Grounc cracking as well as infiltration of colloidal clay and iron compounds (units VII, VIII) may indicate modification of deposits in a periglacial environment.

The studied deposits constituted an ice-marginal moraine Studies of ice-marginal moraine ridges of modern glaciers indicate that they are formed from deformed bedrock and ice-contact deposits as a result of dumping, squeezing, pushing and glaciotectonic deformation processes (e.g., Evans and Hiemstra, 2005; Benediktsson et al., 2009; Roberts et al., 2009 Krüger et al., 2010; Benn and Evans, 2010). The complex of glacigenic deposits near Mąchocice has no features of such moraines. The deposit deformations were interpreted as mostly load-cast structures. However, it cannot be excluded that small advance of the ice front occurred in the early stage of the marginal zone development. It may have caused the compaction of the lower beds of the diamicton (unit II) and silty/sandy interlayers (unit III).

The succession of deposits near Mąchocice and the type o depositional processes suggest accumulation at a stationary glacier margin that creates good conditions for the formation o ice-marginal moraines composed of weakly deformed ice-contact deposits, which are deposited by mass flows (flow tills) and glaciofluvial processes (Benn and Evans, 2010).

In the Kielce-_ _agów Valley, the Local stagnation of the ice front was forced by the geological structure and relief of the bedrock because it consists of permeable limestones and dolomites (i.e., karstified and additionally faulted rocks), and zones of exposed non-karstified rocks. The presence of these karstified rocks caused the escape of subglacial water by a system of underground channels. They drained water into a zone of karst depressions, the location of which was controlled by tectonic factors. The stagnation of the ice front was also facilitated by the fact that the ice sheet lobe passed from the zone of solid rocks (hard bedrock) to the fossil valley depression filled with loose deposits (soft bedrock). Such lithological-structural conditions favoured the stagnation of the ice and formation of "dry ice margins", and determined the location of the end moraine fans (cf. Krzyszkowski and Zieliński, 2002). Thus, isolated fans were formed along the ice margins of such type. It was caused by a limited material supply.

In the lowlands of Northern Poland, where the Weichselian glaciation relief is preserved, such moraines are named "ablation end moraines" (Kozarski, 1995), "glacial end moraines" (Ruszczyńska-Szenajch, 1982) and "end moraine fans" (Krzyszkowski and Zieliński, 2002). In general, they are formed by the ablation of supraglacial material, short tran sport and its deposition at the ice front. Consequently, flow tils interfinger 


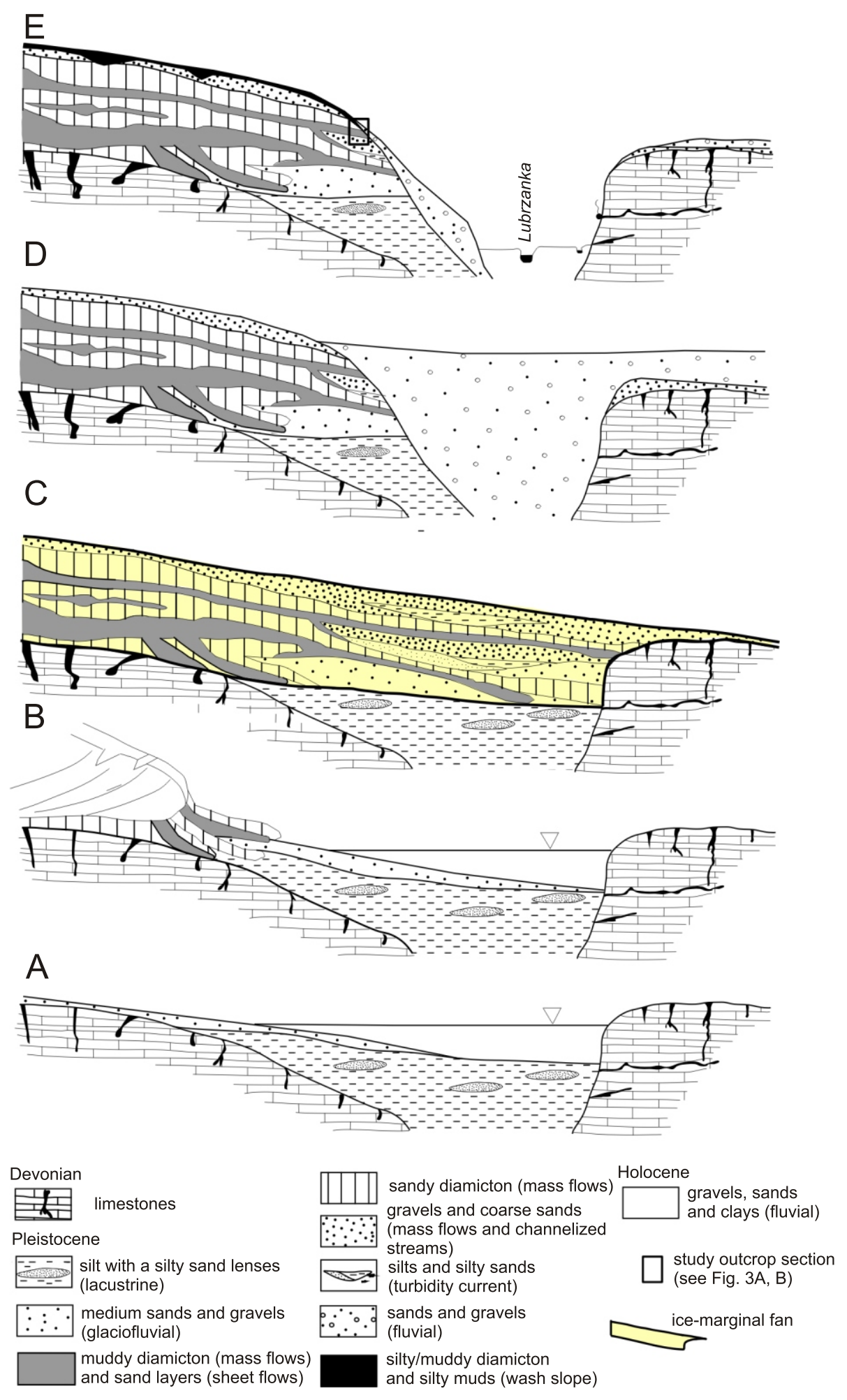

Fig. 11. Model of deposition of glacigenic deposits in the Mąchocice site

A - valley depression as a lacustrine depositional basin, before glaciation; B - advance and stabilization of ice sheet, filling of the lake with deposits, initiation of moraine material deposition in the ice-front zone; $\mathbf{C}$ - deglaciation, deposition of moraine material, formation of local end moraine; $\mathbf{D}$ - interglacial erosion and accumulation, reactivation of fluvial processes in the valley; $\mathbf{E}$ - coexistence of denudation and fluvial processes under periglacial conditions 
with glaciofluvial deposits (Zieliński and Loon, 1996). Krzyszkowski and Zieliński (2002) distinguish three types of end moraines: type A - mass flow deposit-dominated ice-marginal fans, type B - mass flow and waterlain deposit-dominated ice-marginal fans, and type C - waterlain deposit-dominated ice-marginal fans. They are moraines that formed in the conditions of unconstrained sedimentation at the margins of ice sheets. The analysed deposits near Mąchocice are difficult to be classified as a single type of end moraine (may represent an intermediate type between type $\mathrm{A}$ - end moraine, and a proximal part of type B), because the development of glacimarginal fan was spatially limited by the existence of asymmetric valley cut in the Paleozoic bedrock. Therefore, the ice-marginal moraine near Mąchocice should not be morphologically equated with end moraines (sensu Krzyszkowski and Zieliński, 2002) described in the models of ice sheet deposition in a lowland zone. There is a similarity in the lithological and lithodynamical characteristics that determine the classification of the analysed deposits as a marginal moraine.

Stages of deposit sequence formation. The investigated glacigenic depositional sequence developed in several stages (Fig. 11). Its deposition in the pre-Lubrzanka River valley depression was preceded by the existence of a lake (Fig. 11A), as evidenced by the series of silts with silty/sandy interlayqrs, which is identified in boreholes (Fig. 2B). The action of proglacial water during the ice sheet tobe advahce is recordled as the series of sands (investigated in boreholes) and gravelly/sandy deposits (unit I; Fig. 11A, B). These deposits also may have been spread subaqueously. The stagnation of the ice front ("dry ice margins" forced by lithological-morpholog cal conditions) created favourable conditions for mass fow (subaerial and subaqueous; Fig. 11B, C). The extent of activity of such processes was limited by the small size of the valley, and varying height and inclination of its fossil sides. The processes terminated on the SE flank of the valley. Material reeased from the ice was deposited as cohesive debris flow deposits (flow tills of unit II). Shallow sheet flows were active on lows lobes (unit III). In places, the flows were deposited in an ephemeral lake (probably fragments of a disappearing lake, peng filled with deposits), forming the subaqueous, flow sequence of deposits (units IV, V). Progressive warming resulled $n$ the melting out of material and its accumulation on the ice surface. This supraglacial sediment was then redeposited by cohesionless debris flows (flow tills of unit VI).

The analysed series of fan deposits bear traces of modificaion by subsequent denudation and aeolian processes acting under glacial and periglacial conditions (Fig. 11D, E). They eroded and denuded the top part of the series and changed the original glacial landform. The fluvio-aeolian processes deposited the gravel pavement and fine sands, which were then transformed into the breccia (unit VII). The fissure structure (unit VIII) was formed in a dry cold environment as a result of gravitational processes or frost weathering (ground cracking). The iron precipitates, formed under reducing conditions, indicate periodically changing water tables and saturation of the ground. They occur in the grain fractures and in the zones of grain size change. The commonly found iron-manganese micronodules were formed during slow penetration of air into the wet matrix containing $\mathrm{Fe}^{2+}$ and $\mathrm{Mn}^{2+}$ (Todisko and Bhiry,
2008). Microstructures indicating infiltration and deposition of colloidal fraction are also found. The illuvial processes are controlled by the texture and drainage conditions. They are mostl associated with snow melting and ground-ice thaw (Harris and Ellis, 1980). The diamicton with silty/clayey matrix (unit IX), oo curring on the erosion surface, is a record of intense slope-wash development, which was favoured by periodica thaw of permafrost in the periglacial environment (cf. French, 1996; Pawelec, 2011).

\section{CONCLUSIONS}

The investigations, based exclusively on sedimentological (macro-and microstructural) analysis, allowed the identification of depositional environment of the deposits under study, though it was not possible to use geomorphological criteria.

The deposits represent an ice-marginal environment, as indicated by the predominance of sediment-gravity flow deposits (deposited by cohesive and cohesionless debris flows, turbidity currents), a small proportion of sorted deposits, as well as the interfingering/alternating of mass flow deposits and waterlain deposits.

Local stagnation of the ice sheet lobe and the course of processes in the glaciomarginal zone were controlled by the permeable bedrock composed of karstified and faulted limestones, as well as by its relief (occurrence of the fossil valley with asymmetric sides). These conditions contributed to the formation of "dry ice margins".

The deposits may represent an ice-marginal moraine fan. Its development was spatially limited by the existence of asymmetric valley dissection in the bedrock. However, this fan should not be morphologically equated with "end moraine fans" occurring in lowland zones, although there is a similarity in the lithological and lithodynamical characteristics.

The glacigenic depositional sequence developed in several stages. Glaciofluvial deposits were deposited in the then-existing lake. The stagnation of the ice front created favourable conditions for mass flow. Cohesive debris flows were formed, and shallow sheet flows were active on the flow lobes. The deposits were locally deposited in an ephemeral lake (probably fragments of a disappearing lake). Progressive warming resulted in melting out of material on the ice surface, formation of supraglacial melt-out till and development of cohesionless debris flows. The deformation of glacigenic deposits is of loading origin.

The series of glacigenic deposits bear traces of modification by denudation processes acting under periglacial conditions. The gravelly pavement is a record of thermoerosional activity of flowing water. Brecciated deposits supplied with aeolian grains are a record of fluvio-aeolian processes. The fissure structure was formed in a dry environment as a result of gravitational processes and/or frost weathering (ground cracking). The periodical water-saturation of the ground (resulting from thaw of the permafrost active layer) is indicated by the occurrence of micronodules and ferruginous precipitates and the traces of colloidal fraction infiltration. Wash-slope processes are recorded as the erosional surface covered by wash-slope deposits.

Micromorphological studies provided data for genetic identification of the investigated deposits. Analyses of bulk porosity, 
pore types and deformation structures allowed the inference about rheology of deposition and deformation processes, and the determination of processes related to pore-water movement. However, any unequivocal genetic classification of the deposits was not always possible based on the micromorphological analysis. The set of microstructures, identified in the clay-rich diamicton with low porosity - turbate, marble, and indistinct planar shear structures, is not diagnostic because such coincidence of microsturctures is found in both debris flow deposits and subglacial tills. The results of the investigations confirm the opin- ion that detailed and complete explanation of the deposit origin requires both micromorphological analyses and macroscopic field sedimentological and structural studies.

Acknowledgements. This work has been financially supported by the Polish Ministry of Science and Higher Education project No. N306 129337. The valuable comments of J.F. Hiemstra and an anonymous reviewer were of great help in improving the manuscript.

\section{REFERENCES}

Benediktsson, Í.Ö., Ingólfsson, Ó., Schomacker, A., Kjær, K., 2009. Formation of submarginal and proglacial end moraines: implications of ice-flow mechanism during the 1963-64 surge of Brúarjökull, Iceland. Boreas, 38: 440-457.

Benn, D.I., Evans, D.J.A., 1996. The interpretation and classification of subglacially-deformed materials. Quaternary Science Reviews, 15: 23-52.

Benn, D.I., Evans, D.J.A., 2010. Glaciers and Glaciation, 2nd edition. Hodder Education, London.

Bertran, P., Texier, J.-P., 1999. Facies and microfacies of slope deposits. Catena, 35: 99-121.

Blikra, L.H., Nemec, W., 1998. Postglacial colluvium in western Norway: depositional processes, facies and palaeoclimatic record. Sedimentology, 45: 909-959.

Boulton, G.S., 1971. Flow tills and related deposits on some Vestspitsbergen glaciers. Journal of Glaciology, 7: 391-412.

Boulton, G.S.,1978. Boulder shapes and grain size distributions of debris as indicators of transport paths through a glacier and till genesis. Sedimentology, 25: 773-799.

Brewer, R., 1964. Fabric and Mineral Analysis of Soils. John Wiley and Sons, New York.

Czarnocki, J., 1950. Geology of the Łysa Góra Region (in Polish with English summary). Prace Państwowego Instytutu Geologicznego, 1: 1-404.

Czarnocki, J., 1957. Tectonics of the Święty Krzyż Mountains. Stratigraphy and tectonics of the Święty Krzyż Mountains (in Polish with English summary. Prace Instytutu Geologicznego, 30: 31-122.

Dasgupta, P., 2003. Sediment gravity flow - the conceptual problems. Earth-Science Reviews, 62: 265-281.

Evans, D.J.A., Hiemstra, J.F., 2005. Till deposition by glacier submarginal, incremental thickening. Earth Surface Processes and Landforms, 30: 1633-1662.

Evans, D.J.A., Phillips, E.R., Hiemstra, J.F., Auton, C.A., 2006 Subglacial till: Formation, sedimentary characteristics and classification. Earth-Science Reviews, 78: 115-176.

Eyles, N., 1979. Facies of supraglacial sedimentation on Icelandic and Alpine temperate glaciers. Canadian Journal of Earth Sciences, 16: 1341-1361.

Filonowicz, P., 1969. Objaśnienia do Szczegółowej mapy geologicznej Polski w skali 1:50 000, arkusz Bodzentyn (in Polish). Wyd. Geol., Warszawa.

Filonowicz, P., 1978. Mapa geologiczna Polski 1:200 000, arkusz Kielce. A - Mapa utworów powierzchniowych. Mapa podstawowa w skali 1:50 000, arkusz Bodzentyn (in Polish). Wyd. Geol., Warszawa.

Filonowicz, P., 1980. Objaśnienia do Mapy geologicznej Polski w skali 1:200 000, arkusz Kielce (in Polish). Wyd. Geol., Warszawa.

French, H.M., 1996. The Periglacial Environment. Second Edition. Addison Wesley Longman, United Kingdom.
Goździk, J., 1973. Origin and stratigraphical position of periglacial structures in middle Poland (in Polish with English summary). Acta Geographica Lodziensia, 31: 1-119.

Gradziński, R., Kostecka, A., Radomski, A., Unrug, R., 1986. Sedymentologia (in Polish). Wyd. Geol., Warszawa.

Harris, C., Ellis, S., 1980. Micromorphology of soils in soliflucted materials. Okstindan, Northern Norway. Geoderma, 23: 11-29.

Hiemstra, J.F., 2001. Microscopic analyses of Quaternary glacigenic sediments of Marguerite Bay, Antarctic Peninsula. Arctic Antarctic and Alpine Research, 33: 258-265.

Hiemstra, J.F., Rijsdijk, K.F., 2003. Observing artificially induced strain: implications for subglacial deformation. Journal of Quaternary Science, 18: 373-383.

Hiemstra, J.F., Van der Meer, J.J.M., 1997. Pore-water controlled grain fracturing as indicator for subglacial shearing in tills. Journal of Glaciology, 43: 446-454.

Johnson, M.D., 1990. Fabric and origin of diamictons in end moraines. Animas Rivier Valley, Colorado, USA. Arctic Alpine Research, 22: 14-25.

Kasprzak, L., 2003. Model of the Vistulian ice-sheet sedimentation in the Wielkopolska Lowland (in Polish with English summary). Wydawnictwa Naukowe UAM, Seria Geografia, 66: 1-216.

Kasprzak, L., Kozarski, S., 1984. Facial analysis of deposits in the marginal zone of the Poznan Phase of the last glaciation in the central Wielkopolska Lowland (in Polish with English summary). Wydawnictwo Naukowe UAM, Seria Geografia, 29: 1-54.

Kasse, C., Vandenberghe, J., Huissteden, J., van, Bohncke, S.J.P., Bos, J.A.A., 2003. Sensitivity of Weichselian fluvial systems to climate change (Nochten mine, eastern Germany). Quaternary Science Reviews, 22: 2141-2156.

Kessler, T.C., Klint, K.E.S., Nilsson, B., Bjerg, P.L., 2012. Characterization of sand lenses embedded in tills. Quaternary Science Reviews, 53: 55-71.

Kilfeather, A.A., Jaap, J.M., Van der Meer, J.J.M., 2008. Pore size shape and connectivity in tills and their relationship to deformation processes. Quaternary Science Reviews, 27: 250-266.

Konon, A., 2008. Tectonic subdivision of Poland: Holy Cross Mountains and adjacent areas (in Polish with English summary). Przegląd Geologiczny, 56: 921-926.

Kowalczewski, Z., 1963. Transversal foundations in geological structure of Paleozoic socle of the Święty Krzyż anticlinorium (in Polish with English summary). Geological Quarterly, 7 (4): 571-577.

Kowalski, B., 1988. The development of the sculpture of the water gap stretch of the Lubrzanka River Valley through the main range of Świetokrzyskie MTS in the Quaternary period (in Polish with English summary). Przegląd Geograficzny, 60: 635-655

Kowalski, B., 1995. Indications of young tectonic activity in the Kielce-Łagów Valley in the Holy Cross Mountains and its influence on river network (in Polish with English summary). Przegląd Geologiczny, 43: 307-316. 
Kowalski, B., 2002. Origin and age of the flooded and above flooded (high) terrace of the middle part of the Lubrzanka valley in the Holy Cross Mts. (in Polish with English summary). Prace Instytutu Geografii Akademii Świętokrzyskiej w Kielcach, 8: 151-216.

Kowalski, B., Gromada, E., Swałdek, M., 1979. Granulometric and litho-petrographic characteristics of boulder clay from the Wilkowska Valley in the Holy Cross Mountains (in Polish with English summary). Rocznik Polskiego Towarzystwa Geologicznego, 49: 343-377.

Kozarski, S., 1995. Large-clast flow tills in end moraines of SW Pomerania, NW Poland. In: Glacial Deposits in North-Centra Europe (eds. J. Ehlers, S. Kozarski and P.L. Giibbard): 309-317. Balkema, Rotterdam.

Krüger, J., 1984. Clasts with stoss-lee form in lodgement tills: a discussion. Journal of Glaciology, 30: 241-243.

Krüger, J., Kjær, K.H., 1999. A data chart for field description and genetic interpretation of glacial diamicts and associated sediments - with examples from Greenland, Iceland, and Denmark. Boreas, 28: 386-402.

Krüger, J., Schomacker, A., Benediktsson, Í.Ö., 2010. Ice-Marginal environments: geomorphic and structural genesis of marginal moraines at Mýrdalsjökull. Developments in Quaternary Sciences, 13: 79-104

Krzyszkowski, D., Zieliński, T., 2002. The Pleistocene end moraine fans: controls on their sedimentation and location. Sedimentary Geology, 149: 73-92.

Lachniet, M.S., Larson, G.J., Strasser, J.C., Lawson, D.E., Evenson, E.B., Alley, R.B., 1999. Microstructures of glacigenic sediment flow deposits, Matanuska Glacier, Alaska. GSA Special Paper, 337

Lachniet, M.S., Larson, G.J., Lawson, D.E., Evenson, E.B., Alley, R.B., 2001. Microstructures of sediment flow deposits and subglacial sediments: a comparison. Boreas, 30: 254-262.

Lawson, D.E., 1979. Sedimentological analysis of the western terminus region of the Matanuska Glacier, Alaska. Cold Regions Research and Engineering Laboratory Report, 79: 1-112.

Lawson, D.E., 1982. Mobilization, movement and deposition of active subaerial sediment flows, Matanuska Glacier, Alaska. Journal of Geology, 90: 279-300.

Lindner, L., 1984. Region Świętokrzyski (in Polish). In: Budowa geologiczna Polski, 1. Stratygrafia. Część 3b, Kenozoik Czwartorzęd (ed. J.E. Mojski): 33-35, 65-73, 113-145, 255-286, 326-330. Wyd. Geol., Warszawa.

Lindner, L., 2004. Outline of Pleistocene stratigraphy of the Holy Cross Mountains area in light of new data (in Polish with English summary). Prace Instytutu Geografii Akademii Świętokrzyskie w Kielcach, 13: 7-31.

Ludwikowska-Kędzia, M., 2000. Ewolucja środkowego odcinka doliny rzeki Belnianki w późnym glacjale i holocenie (in Polish). Wydawnictwo Akademickie Dialog, Warszawa.

Ludwikowska-Kedzia, M., 2013. The assemblages of transparent heavy minerals in Quaternary sediments of the Kielce-Łagów Valley (Holy Cross Mountains, Poland). Geologos, 19: 95-129.

Ludwikowska-Kędzia, M., Pawelec, H., 2011. Glacigenic sediments near Machocice Kapitulne (Holy Cross Mountains) (in Polish with English summary). In: Geologia i geomorfologia Regionu Świętokrzyskiego (eds. M. Ludwikowska-Kędzia and M. Wiatrak): 71-87. Wydawnictwo Instytutu Geografil Uniwersytetu Jana Kochanowskiego w Kielcach.

Ludwikowska-Kędzia, M., Wiatrak, M., Olszak, I., Bluszcz, A. 2006. Lithostratigraphy of the Pleistocene high meadow terrace of the Łagowica valley near Masłowiec (SE Holy Cross Mountains) (in Polish with English summary). Przegląd Geologiczny, 54: 953-962.

Łyczewska, J., 1971. Quaternary of the Holy Cross Mountains Region. Cenozoic stratigraphy of the Holy Cross Mountains and its margin (in Polish with English summary). Prace Instytutu Geologicznego, 42: 5-86.

Marr, J.H., Harff, P.A., Shanmugam, G., Parker, G., 2002. Experiments on subaqueous gravity flows: the role of clay and water content in flow dynamics and depositional structures. GSA Bulletin, 113: 1377-1386.

Menzies, J., 2000. Micromorphological analyses of microfabrics and microstructures, indicative of deformation processes, in glacial sediments. Geological Society Special Publications, 176: 245-257

Menzies, J., Zaniewski, K., 2003. Microstructures within a modern debris flow deposit derived from Quaternary glacial diamicton a comparative micromorphological study. Sedimentary Geology, 157: $31-48$.

Miall, A.D., 1977. A review of the braided-river depositional environment. Earth-Science Reviews, 13: 1-62.

Miall, A.D., 1978. Lithofacies types and vertical profile models in braided rivers: a summary. Canadian Society of Petroleum Geologists, Memoirs, 5: 597-604.

Miall, A.D., 1985. Architectural-element analysis: a new method of facies analysis applied to fluvial deposits. Earth-Science Reviews, 22: 261-308.

Mohrig, D., Whipple, K.X., Hondzo, M., Ellis, C., Parker, G., 1998 Hydroplaning of subaqueous debris flows. GSA Bulletin, 109: 387-394

Murton, J.B., French, H.M., 1993. Thermokarst involutions, Summer Island. Pleistocene Mackenzie Delta, western Canadian Arctic. Permafrost and Periglacial Processes, 4: 217-229.

Mücher, H.J., Ploey, J., de, 1977. Experimental and micromorphological investigation of erosion and redeposition of loess by water. Earth Surface Processes, 2: 117-124.

Mycielska-Dowgiałło, E., 2007. Research methods for textural features of clastic deposits and the significance of interpretational results. In: Research into the textural features of Quaternary sediments and some dating methods (eds. E.MycielskaDowgiałło and J. Rutkowski): 95-180. The Family Alliance School of Higher Education Press, Warszawa.

Nemec, W., 1990. Aspects of sediment movement on steep delta slope. IAS Special Publication, 10: 29-73.

Nemec, W., Steel, R.J., 1984. Alluvial and coastal conglomerates: their significant features and some comments on gravelly mass-flow deposits. Canadian Society of Petroleum Geologists, Memoirs, 10: 1-31.

Nemec, W., Porębski, S.J., Steel, R.J., 1980. Texture and structure of resedimented conglomerates: examples from Książ (Famennian-Tournaisian), SW Poland. Sedimentology, 27: 519-538.

Pawelec, H., 2011. Periglacial evolution of slopes - rock control versus climate factors (the Cracow Upland, Poland). Geomorphology, 132:139-152.

Phillips, E., 2006. Micromorphology of a debris flow deposit: evidence of basal shearing, hydrofracturing, liquefaction and rotational deformation during emplacement. Quaternary Science Reviews, 25: 720-738.

Pierson, T.C., 1985. Effects of slurry composition on debris flow dynamics, Rudd Canyon, Utah. In: Delineation of Landslide, Flash Flood, and Debris Flow Hazards in Utah. Utah Water Research Publication G-85/03: 132-152. Utah State University, Logan.

Pisarska-Jamroży, M., 2006. Transitional deposits between end moraine and sandur plain in the Pomeranian glaciomarginal zone of NW Poland: a missing component of ice-contact sedimentary models. Boreas, 35: 126-141.

Postma, G., Roep, T.B., Ruegg, G.H.J., 1983. Sandy-gravelly mass-flow deposits in an ice-marginal lake (Saalian, aleuvenumsche Beek Vallay, Veluwe, The Netherlands) with emphasis on plug-flow deposits. Sedimentary Geology, 34: 59-82.

Prażak, J., 2012. Position of hydrodynamic and economic significance of Devonian groundwater reservoirs in the Holy Cross Mountains (in Polish with English summary). Prace Państwowego Instytutu Geologicznego, 198: 1-72.

Racinowski, R., 2008. Significance of heavy minerals analysis in the studies of the Quaternary deposits in Poland. Annales Universitatis Mariae Curie-Skłodowska, sectio B, LXIII, 1: 7-44. 
Racinowski, R., 2010. Main transparent heavy minerals in Quaternary deposits of Poland (in Polish with English summary). Biuletyn Państwowego Instytutu Geologicznego, 438: 99-106.

Roberts, D.H., Yde, J.C., Knudsen, N.T., Long, A.J., Lloyd, J.M., 2009. Ice marginal dynamics during surge activity, Kuannersuit Glacier, Disko Island, West Greenland. Quaternary Science Reviews, 28: 209-222.

Różycki, S.Z., 1972a. Problemy czwartorzędu w Górach Świętokrzyskich (in Polish). Rocznik Polskiego Towarzystwa Geologicznego, 42: 67-79.

Różycki, S.Z., 1972b. Plejstocen Polski środkowej (in Polish). PWN, Warszawa

Ruszczyńska-Szenajch, H., 1982. Depositional processes of Pleistocene lowland end moraines, and their possible relation to climatic conditions. Boreas, 11: 249-260.

Ruszczyńska-Szenajch, H., 1998. Structure of tills: a significant indicator of their genesis (in Polish with English summary). In: Sedimentological and Postsedimentological Structures in Quaternary Sediments and Their Value for Interpretation (ed. E. Mycielska-Dowgiałło): 13-40. Faculty of Geography and Regional Studies Uniwersity of Warsaw, Warszawa.

Ruszczyńska-Szenajch, H., Trzciński, J., Jarosińska, U., 2003. Lodgement till deposition and deformation investigated by macroscopic observation, thin section analysis and electron microscope study at site Dębe, central Poland. Boreas, 32: 399-415.

Shultz, A., 1984. Subaerial debris-flow deposition in the Upper Paleozoic Cutler Fm., W Colorado. Journal of Sedimentology Petrology, 54: 759-772.

Sołtysik, R., 2002. Genesis and age of surface clays in the Holy Cross Mts. (in Polish with English summary). Prace Instytutu Geografii Akademii Świętokrzyskiej w Kielcach, 8:139-150.

Steel, R.J., Thompson, D.B., 1983. Structures and textures in Triassic braided stream conglomerates ("Bunter" Pebble Beds) in the Sherwood Sandstone Group, N. Staffordshire, England. Sedimentology, 30: 341-367.

Stoops, G., 2003. Guidelines for analysis and description of soil and regolith thin section. Soil Science Society of America, INC, Madison, Wisconsin.

Talling, P.J., Amy, L.A., Wynn, R.B., Peakall, J., Robinson, M., 2004. Beds comprising debrite sandwiched within co-genetic turbidite: origin and widespread occurrence in distal depositional environments. Sedimentology, 51: 163-194.

Terpiłowski, S., 2003. New proposal of genetic code of glaciomarginal deposits (in Polish with English summary). In: Sedimentological Analyses of Glaciogenic Deposits (eds. M. Harasimiuk and S. Terpiłowski): 81-93. MCS University, Lublin.

Terpiłowski, S., 2008. Kames as indication of deglaciation of the Podlasie Lowland during the Warta Glaciation (in Polish with English summary). MCS University, Lublin.

Todisco, D., Bhiry, N., 2008. Micromorphology of periglacial sediments from the Tayara site, Qikirtaq Island, Nunavik (Canada). Catena, 76: 1-21.
Vandenberghe, J., 1988. Cryoturbations. In: Advances in Periglacial Geomorphology (ed. M.J. Clark): 179-198, John Wiley and Sons Ltd., Chichester.

Van der Meer, J.J.M., 1993. Microscopic evidence of subglacial deformation. Quaternary Science Reviews, 12: 553-587.

Van der Meer, J.J.M., 1997. Particle and aggregate mobility in till: microscopic evidence of subglacial processes. Quaternary Science Reviews, 16: 827-831.

Van der Meer, J.J.M., Menzies, J., Rose, J., 2003. Subglacial till: the deforming glacier bed. Quaternary Science Reviews, 22: 1659-1685.

Van der Meer, J.J.M., Jaap, J.M., Menzies, J., 2011. The micromorphology of unconsolidated sediments. Sedimentary Geology, 238: 213-232.

Walczowski, A., 1962. Quaternary deposits near Raków and Łagów (in Polish with English summary). Geological Quarterly, 6 (3): 469-482.

Walczowski, A., 1964. Szczegółowa mapa geologiczna Polski w skali 1:50 000, arkusz Łagów (in Polish). Wyd. Geol., Warszawa.

Woronko, B., 2012. Record of aeolian processes in the Pleistocene sandy deposits in the selected areas of central Poland (in Polish with English summary). Faculty of Geography and Regional Studies, University of Warsaw, Warszawa.

Wróblewski, T., 1977. Rzeźba Gór Świętokrzyskich (in Polish). Rocznik Świętokrzyski KTN, 5: 9-22.

Zieliński, T., 1992. Marginal moraines of NE Poland - sediments and depositional conditions (in Polish with English summary). Prace Naukowe Uniwersytetu Śląskiego, 1325: 1-96.

Zieliński, T., 1993. Outwash plains of NE Poland - sediments and depositional processes (in Polish with English summary). Prace Naukowe Uniwersytetu Śląskiego, 1398: 1-96.

Zieliński, T., 1998. Lithofacial identification of alluvial sediments (in Polish with English summary) In: Sedimentological and postsedimentological structures in Quaternary sediments and their value for interpretation (ed. E. Mycielska-Dowgiałło) 193-257. Faculty of Geography and Regional Studies, University of Warsaw, Warszawa.

Zieliński, T., 2003. Is the lithology a useful tool for glaciomargina environment identification? (in Polish with English summary) In: Sedimentological Analyses of Glaciogenic Deposits (eds. M. Harasimiuk and S. Terpiłowski): 95-104. MCS University, Lublin.

Zieliński, T., Loon, A.J., van, 1996. Characteristics and genesis of moraine-derived flow till varieties. Sedimentary Geology, 101: 119-143.

Zieliński, T., Pisarska-Jamroży, M., 2012. Which features of deposits should be included in a code and which not? (in Polish with English summary). Przegląd Geologiczny, 60: 387-397. 